\title{
The Economics and Regulation of Petroleum Futures Markets
}

August 1980

Prepared For:

U.S. Department of Energy

Office of Competition

Washington D.C. 20585

AC01-79 PE 70024 


\section{DISCLAIMER}

This report was prepared as an account of work sponsored by an agency of the United States Government. Neither the United States Government nor any agency Thereof, nor any of their employees, makes any warranty, express or implied, or assumes any legal liability or responsibility for the accuracy, completeness, or usefulness of any information, apparatus, product, or process disclosed, or represents that its use would not infringe privately owned rights. Reference herein to any specific commercial product, process, or service by trade name, trademark, manufacturer, or otherwise does not necessarily constitute or imply its endorsement, recommendation, or favoring by the United States Government or any agency thereof. The views and opinions of authors expressed herein do not necessarily state or reflect those of the United States Government or any agency thereof. 


\section{DISCLAIMER}

Portions of this document may be illegible in electronic image products. Images are produced from the best available original document. 


\section{NOTICE}

This report was prepared as an account of work sponsored by the United States Government. Neither the United States nor the United States Department of Energy, nor any of their employees, makes any warranty, express or implied, or assumes any legal liability or responsibility for the accuracy, completeness, or usefulness of any information, apparatus, product, or process disclosed, or represents that its use would not infringe privately owned rights. Reference herein to any specific commercial product, process, or service by trade name, mark, manufacturer, or otherwise, does not necessarily constitute or imply its endorsement, recommendation, or favoring by the United States Government or any agency thereof. The views and opinions of authors expressed herein do not necessarily state or reflect those of the United States Government or any agency thereof.

Ava1lable from:

National Technical Information Service (NIIS)

D.S. Department of Comnerce

5285 Port Royal Road

Springfield, Virginia 22161

Price: Printed copy: $\$ 8.00$

Microfiche: $\$ 4.00$ 


\title{
The Economics and Regulation of Petroleum Futures Markets
}

\author{
August 1980
}

Prepared By:

Resource Planning Associates, Inc.

Washington, D.C. 20036

DE AC 0179 PE 70024

Prepared For:

U.S. Department of Energy

Office of Competition

Washington D.C. 20585

AC01-79 PE 70024

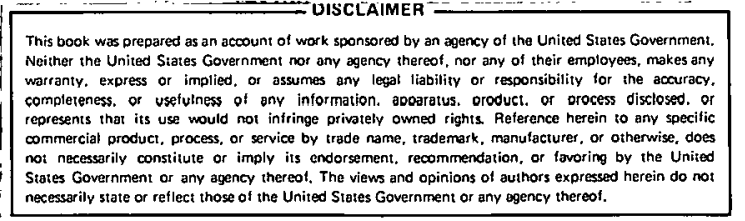


The study was prepared under Department of Energy Contract Number DE AC 0179 PE 70024 for the office of Competition. The contractor was Resource Planning Associates. The purpose of the study was to analyze the development of the futures market in No. 2 oil, assess the potential for futures markets in other petroleum products and crude oll, and ldentify the potential costs and benefits of additional development of petroleum futures markets.

The project was completed under the general supervision of W11liam C. Lane. Arnold $\mathrm{E}$. Safer of Resource Planning Assoclates was the Principal Investigator. 


\section{Contents}

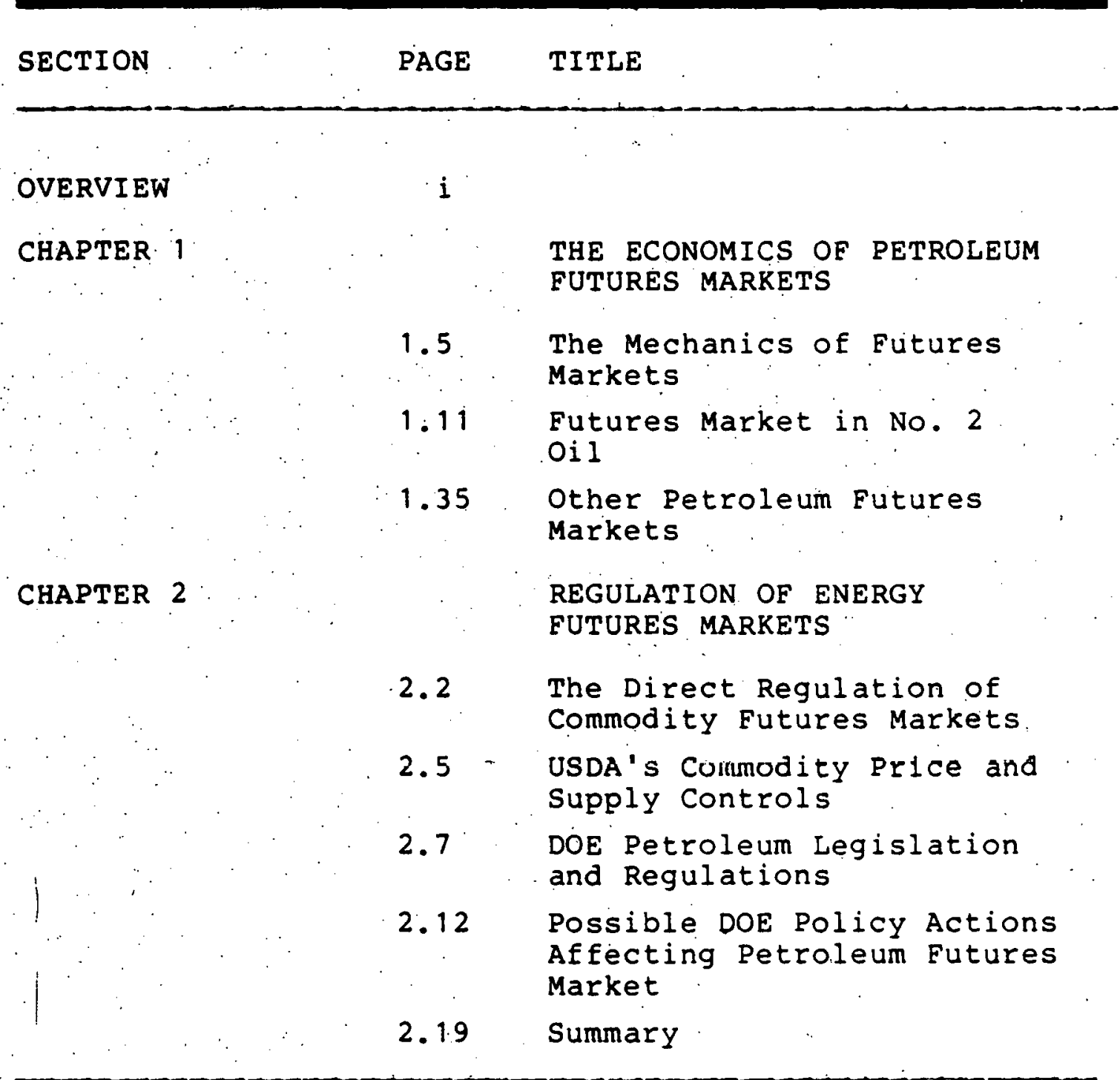

REFERENCES 


\section{Exhibits}

CHAPTER 1

1

2

3

4

5

6

7

8

9

10

11

12

13

14
U.S. Exchanges and Commodities Traded

The Clearing Process

Typical Hedging Transaction

for a No. 2 Oil Marketer

Summary of No. 2 Heating Oil

Futures Contract Terms

B1-Weekly Trading volume

of No. 2 Oil and No. 6 Oil

Monthly Average of Open

Interest

No. 2 Oil Contract Deliveries

Clearing Members of the New

York Mercantile Exchange

Weekly New York Harbor Spot

Prices and Delivery Prices

of No. 2 Oil

Market Activity of the May

1979 No. 2 Oil Contract

Market Activity of the

November 1979 No. 2 Oil

Contract

Market Activity of the

January 1980 No. 2 Oil

Contract

Summary of Crude Oil Futures Contract Terms

Futures Market Potential for Petroleum Products 
EXHIBITS

CHAPTER 2

15 DOE Policies That Would Encourage No. 2 Oil Futures Market

16 DOE Policies That Would Discourage No. 2 Oil Futures Market

$$
\begin{aligned}
& i \cdot x \\
& i_{5}
\end{aligned}
$$


OVERVIEW

The concept of futurity in commodity sales and purchases is nearly as old as commerce itself. As early as the 12 th century, rudimentary futures trading was conducted at medieval fairs in England and France. In the United states, commodities futures trading was closely allied with the development of commerce in Chicago in the 1840s.

U.S. futures markets as we know them first developed to meet the needs of farmers, who brought their grain, livestock, and other commodities to central markets at essentially the same time each year. At the markets, farmers often found that their supply exceeded demand, forcing them to sell their products at low prices. During the nonharvest periods, however, shortages occurred and prices soared as a result. In the midwest, farmers hauled corn to central collection points looated along waterways and canals during the late fall when the roads were still passable. Merchants held the commodities until spring when the waterways to Chicago were free of ice. Owing to the lack of adequate storage facilities and transportation, coupled with the risks and costs of holding inventory, some merchants developed the practice of going to Chicago and entering into contracts to deliver grain or corn at a firm price in the spring. The first "time" or forward contract on record was made on March 13, 1851, and called for the delivery of 3,000 bushels of corn in June at a price of one cent per bushel under the March 13 price.

Forward contracting for delivery solved the basic problems of availability and demand. Because of the lack of organized exchanges, however, it did not resolve the problem of financial risk due to fluctuating prices. As the commodities market grew in volume, however, trading was institutionalized and regulated by exchanges. The Chicago Board of Trade adopted rules for grain futures on October 13, 1865. By 1875, trading rules were complete, the volume of trading was substantlal, and merchants. farmers, and users employed futures contracts to hedge inventories. 
Since that time, futures trading has expanded to a variety of products and exchanges. Cotton futures were first traded at the New York Cotton Exchange in 1870; soybean futures trading 'was initiated at the Chicago Board of Trade in 1936; live beef futures trading began at the Chicago Mercantile Exchange in 1964 ; trading in frozen pork bellies was initiated by the Chicago Mercantile Exchange in 1960; and trading in petroleum products (No. 2 and No. 6 oils) was begun by the New York Mercantile Exchange in 1978.*

Because the futures market in petroleum products is a relatively recent phenomenon, the implications of public policies formulated for that market have not yet been fully explored. To provile the office of Competition of the Department of Energy (DOE) with sufficient information to assess policy alternatives, Resource Planning Associates, Inc. (RPA) was asked to analyze the development of the futures market in No. 2 oil, assess the potential for futures markets in other petroleum products, and identify policy alternatives available to DOE.. To perform this analysis, we first established the criteria for a viable futures market. Then, we examined in detail the experience to date with the 18-month-old futures market in No. 2 oil, and assessed the potential for viable futures markets in No. 6 oil, gasoline, jet fuel, and crude oil. Finally, we examined how existing DOE regulations and prospective actions might affect petroleum futures market development. As a result of our study, we reached the following conclusions:

- The futures market in No. 2 oil is thriving, while the market in No. 6 oil is dormant. The viable No. 2 oil market has been used primarily by the nation's numerous jobbers, distributors, and oil traders, while end-users to date have been somewhat reluctant to participate. In contrast, the No. 6 oil futures market is characterized by few existing participants, but might be enhanced by modifications of the futures contract and changes in existing regulations.

* There was an unsuccessful attempt in 1974 by the New York Cotton Exchange to trade crude oil and propane Eutures. However, the crude contract was not accepted by industry. 
- Under certain circumstances, significant potential exists for viable futures markets in gasoline and crude oil. There is little potential, however, for a futures market in jet fuel.

- As demonstrated by the futures market in No. 2 oil, petroleum futures markets can have a number of beneficial effects on petroleum industry structure and pricing. These benefits include encouraging greater industry competition, easing supply dislocations, price dampening, encouraging competitive pricing, and reducing the need for complex and often burdensome regulation. There are a few, low-probability, potential costs of petroleum futures markets, which are primarily due to such factors as unbridled speculative activity, violations of exchange rules, or failure to deliver. All of these factors, however, can be controlled or prevented through regulation.

- Through its policies, DOE can encourage or discourage the development of petroleum futures markets. Each policy action has consequences both for the petroleum futures markets and the petroleum industry in general. Specifically, DOE can stifle development of the No. 2 oil futures market by reimposing price and supply controls (or, in the case of other petroleum product markets, continuing such controls), enacting overly stringent conservation contingency plans, or discouraging oil companies from using the futures market.

In Chapter 1 we describe in detail the mechanics of futures markets, the experience to date with the No. 2 oil market, and the potential for other petroleum futures markets. In Chapter 2 we discuss the implications of public policy actions on these markets. 
When an individual places an order today for a commodity that is to be delivered tomorrow, a futures contract is created. In such a contract, price is determined at the time the order is placed, and payment made at the time of delivery. Historically, organized futures markets

evolved largely to accommodate the needs of farmers, who harvest their products during a short period of time, and the needs of agricultural product buyers, who use the products throughout the year. Today, futures trading embraces not only agricultural commodities, but a variety of nonagricultural products, such as precious metals, lumber, financial instruments, foreign currencies, and No. 2 fuel oil. (Exhibit: 1 describes the commodities traded and the exchanges.) Whatever the commodity, such trading constitutes a standardized way of ensuring supply at a predictable price, and thus of transferring risk in uncertain situations. In so doing, futures markets allow buyers and sellers to pass the risk of carrying inventories to those who are willing to bear it, and the returns it might bring. This is a function performed by speculators -- those individuals whose normal business operations do not include commodities.

The risks inherent in the businesses that rely on commodities stem from the extended period between initial production and final use, and the seasonal price fluctuations that occur during that period. At any time during the long period of production, storage, processing. distribution, and final use of the commodity, prices may move adversely. For example, if the price of wheat falls between the time the wheat is harvested and the time it is sold, the farmer suffers a loss relative to what he potentially could have earned. Conversely, if the price rises, the farmer gains a windfall: Such a risk is a normal part of business; the futures market, however, provides a way to protect buyers and sellers from this ibusiness risk. By selling a futures contract at a fixed price, the holder of inventory is insulated from future price movements. Similarly, a commodity user can build up low-cost inventory by purchasing a futures contract. 
Exhibit 1

U.S. Exchanges and Commodities Traded

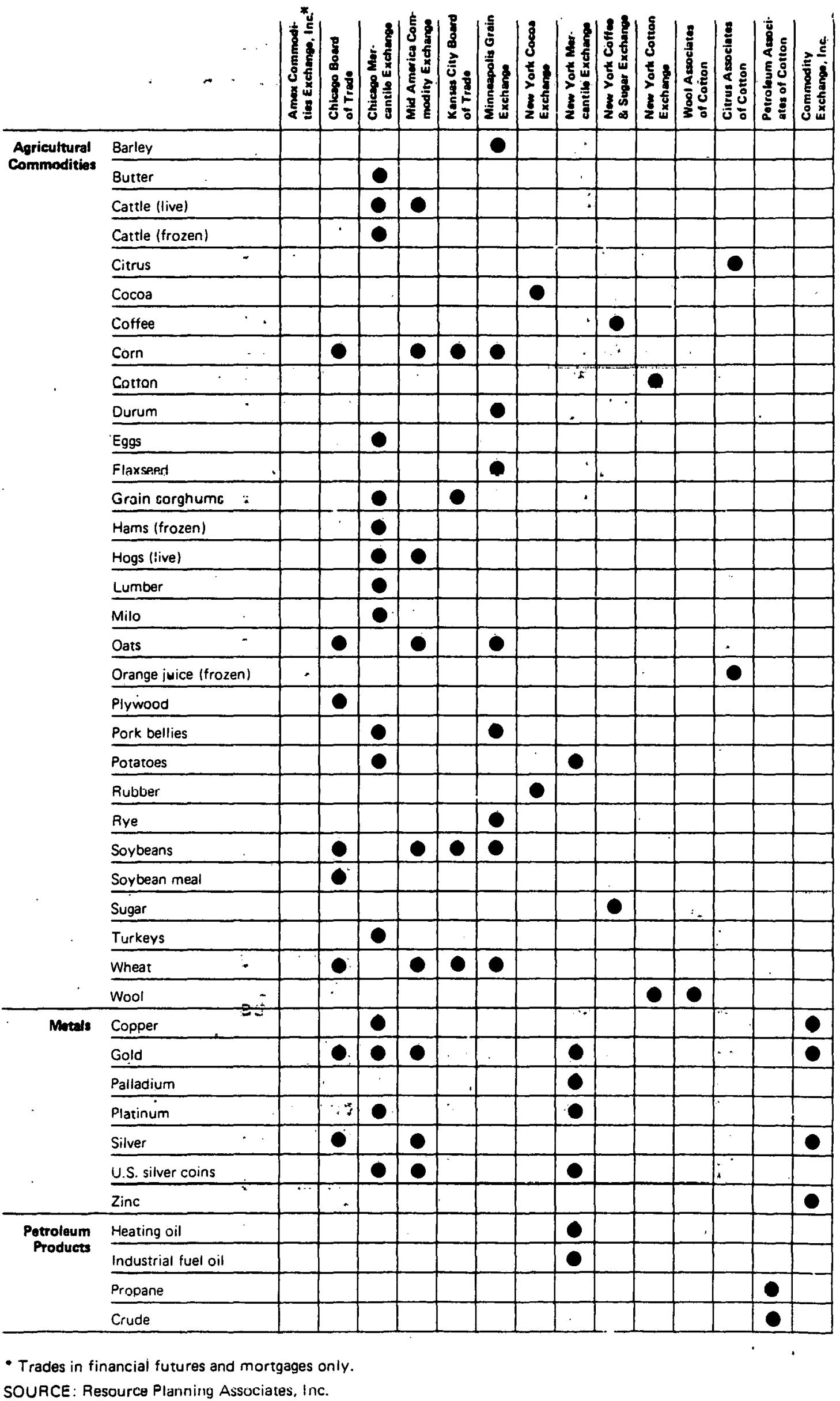


Economists have long viewed commodity markets as the embodiment of many of the features of a truly competitive marketplace, with prices always tending toward their equilibrium levels: All organized commodity markets involve a cash price for current transactions, and a futures price reflecting the markets' expectations of future price pressures. As the time of commodity delivery draws near, the futures and cash prices converge. This occurs because speculators, or "arbitragers," sell overvalued contracts and buy undervalued contracts, thereby creating a situation in which supply and demand for commodities are balanced at a given price.

The economic criteria for a competitive market are similar to the criteria that are necessary for a competitive futures market. The perfectly competitive market has four principal features.

- The product of each seller is interchangeable (i.e.., homogeneous) with that of every other seller.

- Each seller is so small relative to the entire market in which he operates that by himself he cannot influence price.

- There is freedom of entry for all who wish to participate.

- All participants possess complete and timeiy information about the market:

In'the commodities, futures markets, uniform contracts specify the grade and delivery location of winter wheat, or pork bellies, or home heating oil. Thus, one farmer's or oil producer's inventory can be substituted for another farmer's or oil producer's inventory. Sight differences in commodity grade are accounted-for by discounts or premiums on top of the uniform contracts:

In addition, for a futures market to be competitive; it must have enough participants to ensure that no single producer or consumer can affect the price of a product. There is no precise threshold number required; the recently-developed futures market in home heating oil, for instance, gained its initial momentum with only about 30 participants. The existence of a sufficient number of market participants also ensures that the market will be 
liquid. In a liquid market, a buyer (or seller) can easily purchase (or sell) a reasonable amount of contracts at the market price. Conversely, in an illiquid market, the thin volume of trades makes it difficult for a purchaser to find a seller, and vice-versa.

Moreover, there are few barriers to participation in futures markets. The sole price of entry is the cost of the initial margin (down payment) for a contract. In addition, each exchange is serviced by hundreds of registered brokers, each of whom is available by telephone.

Finally, access to market information is a basic prerequisite to efficient price formation in the futures markets. In the futures markets, participants generally obtain information from their brokers, who have direct access to the trading floor.

Indeed, studies have demonstrated that price fluctuations in the futures markets come very close to the theoretical concept of perfectly competitive pricing,* which supports the preceding characterization of futures markets as competitive.

The competitive nature of the futures market is clearly shown in the relationship between spot and futures prices. Financial theory suggests that the current price of a futures contract equals the market consensus of the expected spot price on the delivery date. If this hypothesis is correct, speculators as a group can expect neither to win nor lose in the futures markets. Thus, while each individual speculator hopes to gain, his gain. must come from another speculator's loss. Research has shown that this speculation actually stabilizes cash prices by promoting the rapid assimilation and transmittal of information prior to physical deliveries.**

* Katherine Dusak, in "Futures Trading and Investor Returns: An Investigation of Commodity Risk Premiums," showed that market information is constantly reflected in price by using the random walk hypothesis. Also, Arnold B. Larson, "Measurement of a Random Process in Futures Prices."

** Paul H. Cootner, "Speculation and Hedging" and Hendrik S. Houthakker, "Normal Backwardation" and "Can. Speculators Forecast Prices?" examined the skill with which speculators can forecast prices. The more accurately prices are forecast, the less they will fluctuate. 
Having demonstrated that futures markets are a viable and competitive exchange system, in the following section we examine how such markets operate and the role of various market participants.

THE MECHANICS OF FUTURES MARKETS

The Futures Contract Process

A viable futures market is predicated on a standardized contract, which sets all the terms -- including specification of commodity grade, and when and where the commodity will be delivered -- except the price. Futures contracts are drawn up by and traded on exchanges, such as the New York Mercantile Exchange, the Chicago Mercantile Exchange, and the Chicago Board of Trade.

Buyers and sellers, or their agents, then meet on the floor of the exchange to conduct arm's-length transactions. The resultant accounts are settled by a clearinghouse, which is a party to every transaction. The clearinghouse, as the buyer for all sellers and the seller for all buyers, reconciles all trades daily, collects and pays accounts, and effects delivery ( see Exhibit 2).

Legally, the seller of a futures contract is obligated to deliver the commodity and the buyer is obligated to accept delivery. In established futures markets, however, only 3 percent of all commodities contracts ever result in delivery; on the other hand, a significant number of home heating oil futures contracts have resulted in delivery. This appears to accord with previous market experience, which indicates that new futures markets are used to capture supplies rather than for hedging.

\section{Hedging.}

Farmers, dealers, and end-users of a commodity are greatly exposed to the risk that prices will change. Because a unique feature of futures markets is the fact that the physical commodity need not change hands in a 
The Clearing Process
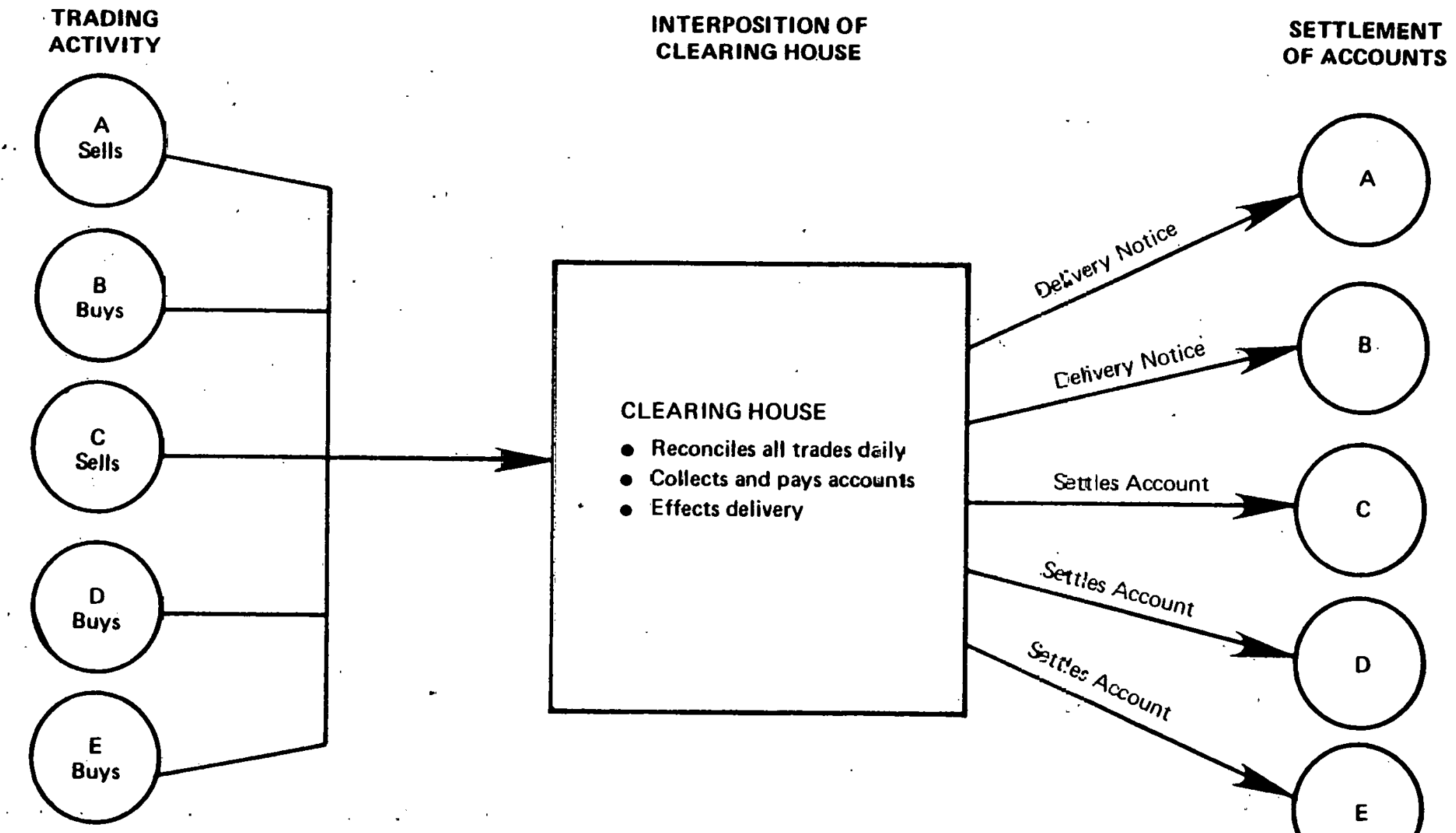

SETTLEMENT

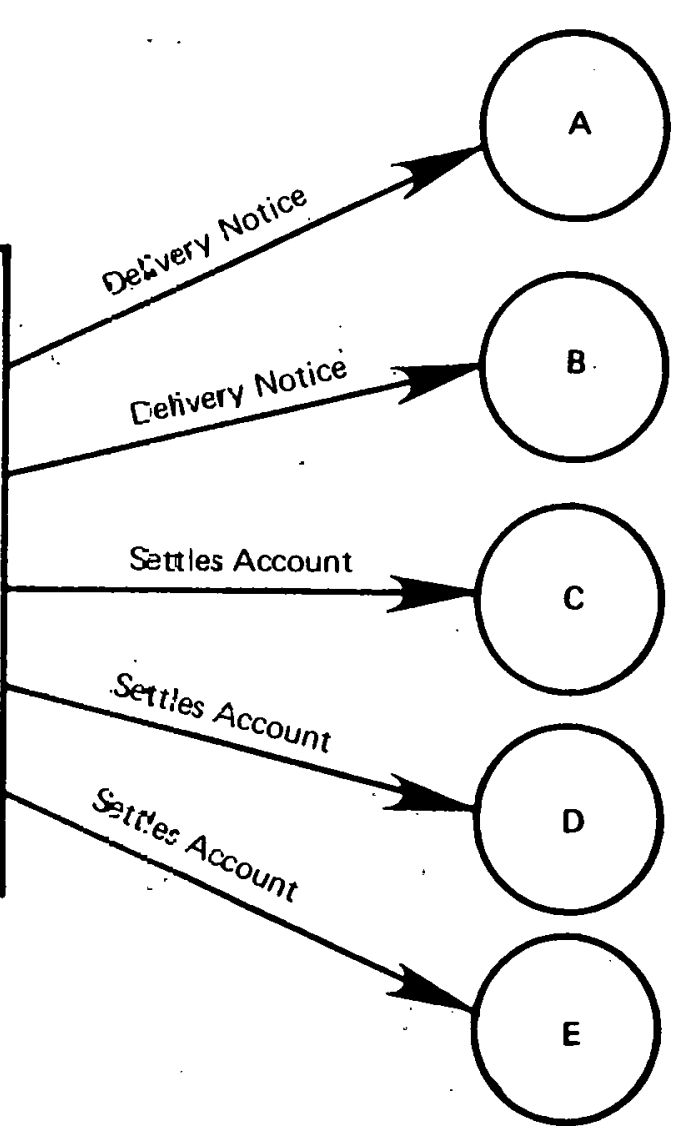

SOÜRCE: Resource Planning Associates, Inc. 
transaction, a contract can be settled by a reversing transaction. This means that a buyer of a futures contract can liquidate his position by selling a futures contract for the same amount. In so doing, holders of inventory can protect their positions by hedging. In commodity markets, hedging is the act of taking equal and opposite positions in the actual commodity and futures markets, with the hope that the net result will prevent a loss due to price fluctuations.

Hedging can be used, for instance, by the producer or. owner of grain as a means of establishing the price of the commodity before, during, and after harvest. To protect the price of existing inventory, the hedger can sell a futures contract in his commodity. In so doing, he is engaging in "short hedging," because he owns the actual commodity and has sold short in a futures contract. With the short hedge, any gain in the price of the commodity is offset by a comparable loss on the futures contract, and any loss on the commodity is offset by a gain on the futures contract. Typical short-hedgers include farmers and oil jobbers in the No. 2 heating oil futures market. (Exhibit 3 shows a typical hedging transaction.)

Hedging also operates for purchasers. Those who buy commodities -- elevator operators, processors, livestock feeders, manufacturers, exporters -- need a continuing supply of raw material throughout the year. Like sellers, buyers are subject to price fluctuations in the marketplace. At the same time, however, buyers must have a reasonable idea of the cost of their raw material over the period of the futures contract, in order to enter into contracts with their customers.

The buying hedge involves the purchase of futures to protect against a possible price increase of the actual commodity. In the buying hedge, also known as the long hedge, the first transaction in the futures market is a purchase rather than a sale. 


\section{Exhibit 3}

Typical Hedging Transaction

for a No. 2 Oil Marketer

Cash Market

August 1: Placing the Hedge

Refiner enters into a contract to supply $4,200,000$ galions of No. 2 oil in December, with the price of December delivery left open. Refiner estimates cost of refining and storage at $75^{t}$ per gallon.

\section{November 30: Removing the Hedge}

Refiner delivers No. 2 oil to customer. Spot price is now 90 per gallon, which the refiner receives.

Profit: $15 \%$ per gallon
Futures Market

The refiner sells (goes short) 100 No. 2 contracts $(4,200,000$ gallons) for December delivery. The futures price is now $80 \%$ per gallon.

Refiner buys (goes long) 100 No. 2 contracts. at $95 \%$ per gallon.

Los: $15 \%$ per gaillon

NOTE: As the result of this hedge, the refiner

neither gains nor loses. (Net result: $\$ 0.00$ per gallon.)

SOURCE: Resource Planning Associates, Inc. 
While the hedgers transfer risk, not all those who bear the risk are speculators.* For example, a farmer who is short-hedging may trade with. a grain processor who is long-hedging.

\section{Speculating}

As pointed out previously, speculators serve a number of legitimate market functions. First, findings show that speculation actually stabilizes prices by promoting the rapid assimilation and transmittal of information. * second, the greater the proportion of speculation to purely commercial hedging, the smaller the spread between futures and spot prices.*** Finally, the market liquidity provided by speculation tends to reduce price distortions, and some studies suggest that speculation helps dampen excessive: price movements. $t$

\section{Basis}

The difference hetween the cash price of a commodity and its price on a futures market is known as the basis. This difference is due to many factors, including: supply and demand for the commodity; supply and demand for substitute commodities; transportation costs; and available storage space. For grain, the basis is at its widest point during the harvest period, reflecting the

* In general, a hedger is an individual in the trade with a commodity inventory. The activities of a hedger in the futures markets are considered part of normal business operations, and his profits and losses are treated as ordinary income for tax purposes. In contrast, a speculator has no commodity inventory, and the Internal Revenue Service treats the speculator's profits and losses as capital gains or losses.

* Houthakker.

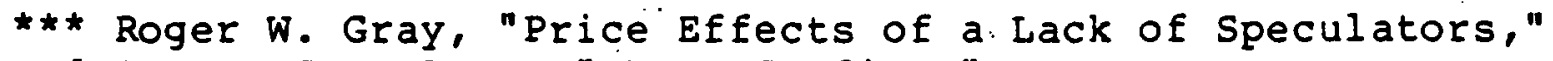
and Lester G. Telser, "Wheat Studies."

t William Tomek and Roger W. Gray, "Temporal Relationships Among Prices on Commodity Futures Markets: Their Allocative and Stabilizing Roles." 
demand for storage space and transportation. In contrast, the basis is at its narrowest point just before the new crop is harvested.: A similar pattern has been exhibited in the basis behavior of No. 2 oil. The basis is at its widest point during the summer, when jobbers are beginning their summer fill; the basis is at its narrowest point during the winter, when consumption is at its peak and storage inventory is being. drawn down.

In general, the futures price is higher than the cash price, particularly during periods of inflation. However, when a commodity is in great demand, futures prices tend to be discounted. The result is an "inverted market," in which cash prices exceed futures prices.

\section{Storage Facilities}

Given the relationship between futures prices and storage space, it is useful to consider the role of storage.

The availability of storage capacity is important to a functioning market, because futures markets rely on storage facilities to effect delivery.

In addition, the amount of inventory that individuals are willing to store in available facilities is a function of expected futures prices. Inventory levels reflect the actual cost (e.g., insurance, interest, storing, leasing) of holding a commodity, plus the expected return on the investment, which depends on the risk. The expectation of a considerable increase in the price of the commodity creates an incentive to hold larger inventories. On the other hand, the expectation of only a slight increase, or even a decrease, in price is a disincentive to hold larger inventories.

The relationship between expected price and inventory level has been observed in a number of commodity markets. For example, during the fall of 1979, expectations of rising No. 2 oil prices induced many jobbers, terminal operators, and traders to hold large supplies of home heating oil. The inventory buildup was due in part to DOE, which established targets for No. 2 storage. Because of the warmer-than-normal winter, however, the expected demand for heating oil never materialized. As a result, inventories had to be liquidated at prices below 
those expected, causing losses to a number of these organizations. Had they chosen to hedge in a futures market, many would have been protected from such losses.

FUTURES MARKET IN NO. 2 OIL

In this section, we analyze the performance of the futures market in No. 2 oil. As a first step in our assessment, we identified specific criteria that must be satisfied for the successful development of a futures market in any new product. We distinguished at least three such criteria.

First, there must be a sufficiently large number of buyers and sellers so that the organized exchange system (i.e.; the trading floor) widens the market potential for each individual participant. A market dominated by a few large buyers and sellers is usually characterized by a negotiated or administered price, rather than by a price that reacts rapidly to changing supply and demand conditions. When there are many market participants, the rapid price and volume information that is generated by an exchange trading system becomes a valuable mechanism. for decision making.

Second; for a successful futures market there must be inherent price uncertainty. The uncertainty, which stems from the market participants' changing expectations, can occur because of technological, regulatory, and competitive pressures, business-cycle fluctuations, or seasonal shifts in demand and supply.

Third, a successful futures market requires sufficient storage and transportation capacity in the distribution system to facilitate trading. This is because the ability to make or take delivery at a large number of storage facilities is a precondition of open, arm's-iength trading. Since inventories often represent a hedge against the uncertainty of delivery or price, there must be adequate storage to accommodate the fluctuations in production, delivery, and consumption.

A fourth criterion is critical to successful futures market trading -- product homogeneity. When commodity or product futures are traded, a sufficiently standardized unit is needed on which to base the impersonal trading of 
the exchange floor. In a "spot" or "merchant" market, buyer and seller talk directly with each other, negotiating quality specifications, delivery arrangements, and payment terms as well as price. Organized exchange trading. On the other hand, is based on a standardized legal contract that specifies -- in advance -- to all market participants the details of the commodity or product being bought or sold. In turn, the market participants must agree to these contract specifications in advance. To accommodate most participants, the commoditips or products traded must be sufficiently homogeneous not only in terms of quality, but also with respect to delivery, default, and payment terms.

\section{Petroleum Industry Characteristics}

Having determined the preconditions for a successful futures market, we then examined the market characteristics of the petroleum; industry.

The No. 2 oil futures market now operating at the New York Mercantile Exchange (NYME) is helping to relieve a number of industry pressures that have arisen since 1974. These pressures, which exist in one form or another across the entire petroleum industry, stem largely from the organization of the industry's product distribution system and the financial relationships on which that system depends. The distribution of residual fuel oil and gasoline at the wholesale level, Iike that of middle distillates (No. 2 oil and diesel fuel) is carried out primarily by a large number of independent jobbers. The jobbers, who range from large terminal operators and mass distribution organizations to smaller localized delivery firms and independently owned service stations, differ in size and number according to the region of the country where they are located and the proportion of each type of petroleum product that they distribute.* In the northeast and midwest, residual fuel oil is an important energy source for industrial and power plant uses, while natural gas tends to dominate these energy markets in the south and west. The use of heating oil is more widespread, with a

* A detailed analysis of the market for middle distillates is found in Middle Distillate Market Profile, prepared for the U.S. Department of Energy by R. Shriver Associates, July 1979 . 
heavy concentration of the fuel on the west coast as well as in the east and midwest, while diesel fuel is used extensively in the south and west. Motor gasoline is of course distributed nationwide, but oil-company-owned service stations are more common in the south and southwest than in other regions of the country.

For all three petroleum products, however, the jobber groups face a set of new business problems resulting from the changing economic pressures on their suppliers -- the oil refining industry, and primarily the major oil companies. The relationship of downstream marketing activities to industry financial structure has been the focus of much study and debate. According to one point of view, many major oil companies before 1974-1975 subsidized downstream marketing activities with profits from crude operations, thus reducing competition.* However, other studies have argued convincingly that the branded dealer network was created in a competitive atmosphere and was not designed to slow the development of private brand marketers.**

According to the former point of view, in the united States, the import quota kept out "cheap foreign oil," state prorationing kept domestic supply and demand in balance, and various tax incentives (the depletion allowance and intangible drilling write-offs) made crude oil production the most profitable part of the oil business. In particular, a relatively high return on investment was sought in the exploration/production end of the business and a "normal" manufacturing return was the goal in refining. At the same time, the marketing function was viewed as a way of maintaining a secured outlet for the more profitable upstream functions. In effect, the higher profits on crude oil subsidized the low to negative returns in marketing.

* In The control of Oil, John M: Blair makes a case supporting this hypothes is. Independent gasoline marketers have been among the most vocal proponents of this theory.

** U.S. Department of Energy, "The State of Competition in Gasoline Marketing." Part I, May 1980. 
Because of the industry financial structure, the oil refining company provided an "insurance policy" for the independent distributor. By absorbing the normal fluctuations in volume that the distributor incurred, the oil company maintained a favored relationship with the distributor. If the distributor purchased too much oil in any given period, the oil company would take it back; if the distributor went short in any given period, the oil company would supply him with more oil. This system, which worked to the financial advantage of the jobber, relieved him of much of the inventory and price risk normally associated with an independent wholesale business.

By the mid- to late 1970s, however, the situation had changed. Not only had surplus turned to scarcity, but the profitability structure had changed. The import quota was gone, the prorationing system became irrelevant as domestic oil wells produced at maximum capacity, and the depletion allowance was eliminated or severely curtailed. In addition, domestic crude oil price controls were imposed by Washington.. All these events affected the profitability of the domestic crude oil business for the major oil companies. Meanwhile, the OPEC nations rapidly eliminated much of the profit in the international crude oil production business. As a result, oil profitability has shifted downstream, to the refining and marketing aspects of the business. For the independent oil jobber, the insurance policy provided by the major oil company is rapidly disappearing. Thus, the jobber is now truly at risk when he purchases from the oil company and when he keeps his oll in inventory. If he misjudges his market, holding too much or too little inventory, the major oil company will no longer protect him financially.

The growth of the spot market in petroleum products is one result of the change in petroleum industry operations. Some jobbers have become oil traders, maintaining a constant flow of market information with other jobbers. Under this system, a distributor who has too much product in a given period will seek a distributor who has insufficient product, and vice versa. It was the growth in spot market trading that provided the major impetus to the introduction of the No. 2 oil futures market at the NYME. A natural outgrowth of such trading activity has been the creation of a wider information network and the opportunity to buy and sell at a fixed price in the futures as well as in the spot (or cash) market. 


\section{Case study}

On November 14, 1978, the NYME initiated futures trading in two petroleum products: low-sulfur $(0.2$ percent $)$ No. 2 fuel oil and low-sulfur ( 0.3 percent) No. 6 residual fuel oil. While the No. 6 market has stagnated (for reasons that we will discuss in the following section), the futures market in No. 2 oil has experienced steady growth. The major market participants in the No. 2 oil market are refiners, heating oil distributors, and end-users, all of whom employ the futures market as a way both of hedging price rises and of obtaining supplies. Continuing uncertainties about energy prices and supply will only boost the trading volume, making the market an increasingly significant factor in the U.S. petroleum industry.

Futures contracts in No. 2 oil are traded on the floor of the NYME, located in the world Trade Center. Trading in No. 2 oil begins 1 year prior to the delivery month, in thousand-barrel contracts that specify delivery in New York Harbor: *

To purchase a No. 2 oil contract, a market participant must deposit at least a 5-percent original margin, which ranges from $\$ 1,500$ to $\$ 2,000$, depending on price fluctuations. The contract, summarized in Exhibit 4, specifies maximum and minimum price fluctuations and product quality. In addition, most brokerage firms require the ir customers to provide cash reserves in excess of immediate commitments to provide for any variation in price. The price fluctuates daily, and the contract holder thus gains or loses daily. If the price of the oil rises, the "short" must pay the "long"; if the price falls, the "long" must pay the "short." In practice, the broker keeps the funds in the customer's account, which is called "marking to the market."

* New York Harbor includes all major storage facilities that have a comparative common transportation differential. Thus, the area is bounded by the East River west of Hunts Point; Gowanus Bay west of the Hamilton Avenue Bridge; the Hudson River south of the George Washington Bridge; the Upper Bay; the Narrows; the Lower Bay west of Norton Point; the Newark Bay; the Hackensack River and Passaic River south of the Pulaski Skyway Bridge; the Kill Van Kull; and the Arthur Kill and the Raritan River. east of the Garden State Parkway Bridge. 


\section{Exhibit 4}

\section{Summary of No. 2 Heating Oil Futures Contract Terms}

Contract Unit:

Delivery Point:

Price Quotation:

Minimum Price Fluctuation:

Maximum Daily Price Limit:

\section{Product Specifications}

Gıávily.

Flash:

Carbon Residue:

Viscosity:

Water and Sediment:

Pour Point:

Distillation:

Sulfur:

Ash:

Trading Hours:

Delivery Months:
42,000 U.S. gallons ( 1,000 U.S. barrels $)$

New York Harbor

Dollars and cents per gallon

$\$ 0.0001(0.01 \notin)$ per gallon (equivalent to $\$ 4.20$ per contract unit)

$\$ 0.02(2 \$) ; \$ 0.03(3 \$)$ on third day after two limit days. $\$ 0.04$ (4F) thereafter, all movers qraduated. (No limit on last trading day of month preceding delivery month.)

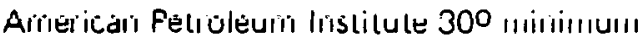

$1000 \mathrm{~F}$ minimum

$0.35 \%$ maximum on $10 \%$ bottoms

Kinematic, Centistockes at $1000 \mathrm{~F}, 2.0$ minimum. 3.6 maximum

$0.5 \%$ maximum

OOF maximum

$90 \%$ point, $540 \circ \mathrm{F}$ minimum, $6400 \mathrm{~F}$ maximum

$0.20 \%$ maximum

$0.1 \%$ maximum

10:30 a.m. $-2: 45$ p.m.

Active markets now maintained each month for succeeding 9 months

SOURCE: New York Mercantile Exchange. 
Trading Volume

A viable market is characterized mainly by a trading volume that is sufficient to supply liquidity, i.e.. average-sized trade can be accommodated without substantially moving the price. From the time of inception of the No. 2 oil futures market to mid-June 1979, the daily volume of trading was relatively light (10-100 contracts). After that, trading volume climbed dramatically, reaching its height during November 1979 with approximately 520 contracts traded daily. This activity coincided with investor concern about a shortage of heating oil that had its roots in the prediction of a colder-than-normal winter, in low inventories of heating oil, and in the Iranian crisis. At present, daily trading volume has settled down to a range of between 300 and 450 contracts. (Exhibit 5 shows biweekly trading volumes of No. 2 Oil and No. 6 oil between November 1978 and May 1980.) The threshold volume for a viable No. 2 oil market is approximately 200-300 contracts a day. A typical jobber trade in the New York spot market is a barge lot of 15,000-20,000 barrels (15-20 contracts). A typical jobber trade in the futures market -- by extension -- would constitute less than 10 percent of the daily trading volume, and could be accommodated without affecting the commodity price.

The availability of storage is an important factor in assessing the potental volume of the futures market. While the precise amount of storage facilities in New York Harbor is uncertain, the present storage available to the NYME should permit it to double its present deliveries of 500,000 bbls per month. However, this delivery capability is but a fraction of the total storage capacity for No. 2 oil. During the winter months, the New York spot market may trade as much as 1 million bbls per day.

A second determinant of market viability is the amount of open interest -- or the number of outstanding contracts. Two people -- a buyer and a seller -- are required to establish a contract. The open interest at any point, therefore, is the number of short contracts, which is equal to the number of long contracts.

Since the inception of the No. 2 oil futures market, open interest has climbed sharply. As shown in Exhibit 6, the 


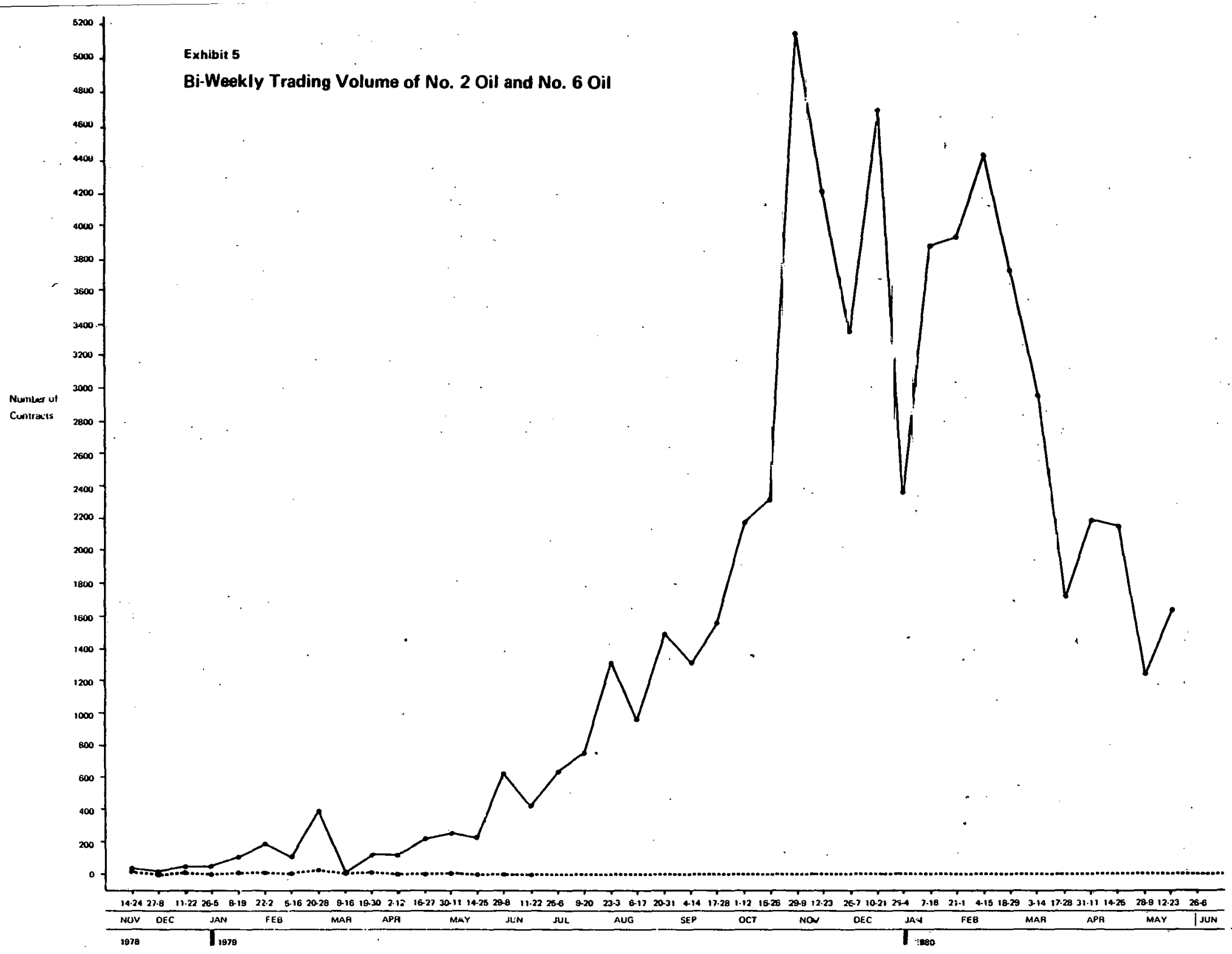

SOUFCE: N.Y.M. ミ, Dally Fulueres Repuri 


\section{Exhibit 6}

Monthly Average of Open Interest*

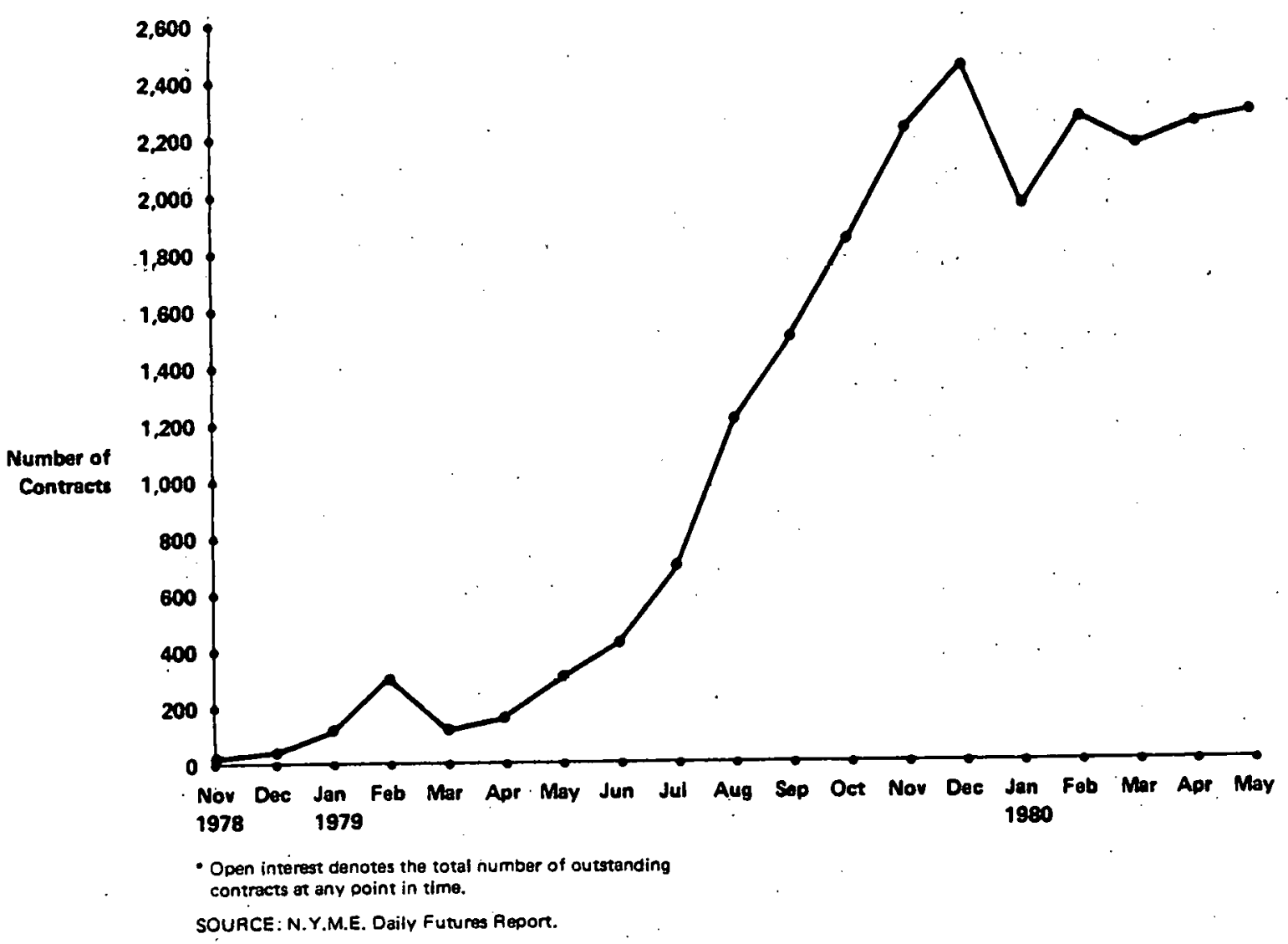


monthly average open interest in November 1978 was 11 contracts. In June 1979, open interest stood at 424 contracts; in March 1980, open interest was 2,209 contracts. The Wall street Journal requires a minimum of 5,000 open interest to publish the daily trading results. Barron's, which requires a 2,500 open interest, has recently begun to publish the NYME No. 2 oil results.

The amount of open interest on a particular contract follows a standard pattern through its 1-year life. At the beginning of trading, open interest is low, but as the months go by, it increases steadily. Open interest begins to fall 2-3 months prior to contract expiration, as investors liquidate positions. In the month of expiration, open interest plunges to zero, as market participants either choose to make or take delivery.

\section{No. 2 oil Market Participants}

The futures market in No. 2 oil has been used by refiners, independent oil dealers, jobbers, bulk wholesalers, pipeline companies, and end-users, among others.* These participants use the market to reduce price risk through hedging, to obtain supply by purchasing contracts, and to reduce inventory holding costs.

By hedging, a heating oil distributor, refiner, jobber, wholesaler, or end-user can reduce price risks. For example; a large industrial user can protect himself against future price rises by selling a futures contract commitment. Similarly, a refiner can protect himself against decreases in product prices by shortseling obligations to deliver at a certain price at some time in the future. Although the refiner foregoes the potential gains from price increases as a result, he reduces risk and locks in refinery margins. End-users can employ the futures market in the same way. By buying contracts long, a trucking firm or building owner locks in future purchases at a known price, thereby increasing certainty about profit margins.

* To date, major oil companies have been slow to engage in No. 2 oil futures trading. Sun Oil Company, however, recently became a member of NYME. 
When buying long as well as selling short, the hedger obtains certainty. Because futures prices and spot prices move together, if the hedger loses in the futures market, he gains in the cash market, and vice versa. The hedger -- be he buyer or seller -- is thus able to eliminate the risk of the price moving against him. Should the price move in favor of the hedger, on the other hand, he must forfeit the gain.

The principal market participants in the No. 2 oil futures market have been jobbers and distributors, who can go either long or short because they must purchase, store, and resell the product. A short selling strategy protects the jobber against depressed winter prices and a lowerthan-expected volume. A long purchasing strategy protects the jobber against unexpected price increases from his supplier, and gives him fixed costs on which to base his contracts to supply end-users.

In the No. 2 market to date, a relatively high percentage of the outstanding contracts -- open interest -- has culminated in delivery. The NYME's first No, 2 oil futures deliveries were completed in March 1979, when 130 contracts ( $5.4 \mathrm{million}$ gallons) representing 35 percent of open interest were delivered. During the May delivery period, the NYME handled 41 deliveries, nearly all of the open interest. During the July 1979 delivery month, 38 of the 90 contracts culminated in delivery, or 42 percent of the total. This pattern has continued to the present time. In May 1980 , 175 of the 485 contracts traded culminated in delivery. (Exhibit 7 contains an enumeration of deliveries to date of No. 2 oil contracts.) In other futures markets, only 2-3 percent of all open interest results in delivery.

The large number of deliveries associated with the No. 2 oil futures market does not appear to be a characteristic of the product traded, but rather may be related to the relative newness of the market. In the early years of trading in other commodities, market participants have tended to use the market to obtain supply. As the market grows and liquidity improves, however, participants increasingly use the market for financial purposes -hedging and speculating. In the grain futures market, for instance, purchasers and sellers of futures contracts tend to use the market not for supply, but as a financial hedge! 
Exhibit 7

No. 2 Oil Contract Deliveries

\begin{tabular}{lccl}
\hline & & \multicolumn{2}{l}{ Deliveries } \\
\cline { 3 - 4 } $\begin{array}{l}\text { Contract } \\
\text { Month }\end{array}$ & $\begin{array}{l}\text { Open } \\
\text { Interest }\end{array}$ & Number & $\begin{array}{l}\text { As Percent } \\
\text { of Open } \\
\text { Interest }\end{array}$ \\
\hline March 1979 & 366 & 130 & 35 \\
May 1979 & 49 & 41 & 84 \\
July 1979 & 90 & 38 & 42 \\
September 1979 & 233 & 54 & 23 \\
November 19/4 & 214 & 82 & 38 \\
December 1979 & 767 & 418 & 54 \\
January.1980 & 576 & 191 & 33 \\
February 1980 & 885 & 241 & 27 \\
March 1980 & 891 & 382 & 43 \\
April 1980 & 343 & 141 & 41 \\
May 1980 & 485 & 175 & 36 \\
June 1980 & 293 & 120 & 41 \\
\hline Total & & $\mathbf{2 , 0 1 3}$ & \\
\hline
\end{tabular}

SOURCE: NeW York Mercantile Exchange. 
The delivery process itself is governed by the clearinghouse. After consulting its records, the clearinghouse passes along notices of delivery to clearing firms, which are members of the clearinghouse. (Exhibit 8 lists all NYME clearinghouse members.) Most deliveries were completed by book transfer, with no physical movement of the oil.*

To facilitate deliveries under terms and conditions that differ from those specified in the futures contract, the NYME has established an Exchange of Futures for Product (EFP) mechanism. The EFP permits buyers and sellers to customize the delivery mechanism to suit their own needs. Thus, a buyer can use the EFP mechanism to arrange for delivery of the product in Boston, Chicago, Houston, or Philadelphia, or to make delivery earlier or later than NYME rules would otherwise permit, or to arrange for the delivery of a slightly different grade of product. To arrange an EFP transaction, either the buyer or the seller must have a long or short position in the futures market, and both must mutually agree on price, location, quantity adjustment, payment, and time of delivery.*

Under the EFP system, refiners and distributors of No. 2 oil can use the futures market to arrange for swaps of product, with individually negotiated changes in quality and the time and location of delivery.

* A book transfer can be accomplished when the seller already has the oil in the storage facility desired by the buyer. Thus, ownership is transferred simply by changing the "books" of the storage facility.

** If these two requirements are fulfilled, the buyer and seller can then request that an EFP transaction be completed and the trade registered with the NYME. The quantity, buy and sell broker, and delivery month are posted. Although the price is entered in the computer system; it is not posted. The price and modified delivery procedures are only given to the clearinghouse as proof of an agreement between the parties in order to ensure for the Exchange that the physical product will be transferred. Once an EFP is completed on the trading floor, both parties are obligated to prove that the product has transferred hands within a reasonable time period. The NYME is required to request proof of transfer. of the product from clearinghouse members. 


\section{Exhibit 8}

\section{Clearing Members of the New York Mercantile Exchange}

ACLI International Commodity Services, Inc. ACLI International Incorporated Ametalco, Inc.

Aron \& Co., Inc., J.

Aron Commodities Corporation, J.

Aroostock Agricultural Service, Inc:

8\&B Commodities

Bache Halsey Stuart Shields, Incorporated

Badger, Joseph E.

Ralfnur. Maclaine. Inc.

Bear, Stearns \& Co.

Beaver Brook Commodities

Brandeis, Goldschmidt \& Co., Inc.

Brandeis, Goldschmidt \& Co. (Commodities), Inc.

Brody, While \& Cu., lici.

Bushwick Commission Co., Inc.

Cargill Investor Services, Inc.

Clayton Brokerage Co.. of St. Louis, Inc.

Commodity International

ContiCommodity Services, Incorporated • .

Crystal, Stern

Dean Witter Reynolds, Inc.

Delos Commodities, Inc.

Drexel Burnham Lambert, Inc.

Edwards \& Sons, Inc., A.G.

Fahnestock \& Co.

Freehling \& Co.

Friedman \& Co., Ray E.

Gerald Metals, Inc.

Gill \& Duffus Services, Inc.

Grappel Trading Co., Inc.

Heinold Commodities, Inc.

Helfer Commodities Corp.

Hutton \& Co.. Incorporated, E.F.

Kipnis \& Co., A.G. Becker

Klein \& Co.

Lazarus \& Company, Melvin

Levy Commodities
Leytess Metal \& Chemical Corp.

Lincolnwood, Inc.

Lind-Waldock and Company

MFX Commodities

MPG Commodities, Inc

MSP Trading, Inc.

Macro International Group, Inc.

Marc Commodities Corp.

Merrill Lynch, Pierce, Fenner \& Smith, Inc.

Maduff \& Sons, Inc.

Metal Traders, Inic.

McCormick Commodities, Inc.

Mocatta Metals Corp.

PM Clearing

Paine, Webber, Jackson \& Curtis, Inc.

Paris Securities Corp.

Philipp Brothers Trading Corp.

Pollak \& Co.. Harvey B.

Pollak \& Co., Inc., Henry A.

Pressner Trading Corp.

Primary Metal \& Mineral Corp.

RAM Commodities, Inc.

R. T. B., Inc.

Republic Clearing Corp.

Richardson Securities, Inc.

Rosenberg, Inc.., Alan J.

Rosenberg Commodities, Inc.

Rosenthal \& Company

Servonet, Inc.

Shearson Loeb Rhoades, Inc.

Siegel Trading Company, Inc., The

Sinclair \& Co., Inc.

Smith Barney, Harris Upham \& Co., Inc.

T\&S Commodities Inc.

Thomson McKinnon Securities, Inc.

Three G Trading Corp.

United Equities (Commodities) Co.

Volkart Brokerage, Inc. 
For example, refiners are commonly faced with the problem of an unforeseen shortage of product at one point in time, and a potential surplus of product at another. Without a futures market, a refiner who has a shortfall of No. 2 oil today but expects a surplus in 3 months' time would have to swap actual product with a trader or another refiner who has a surplus today but anticipates a need 3 months from now. With a futures market featuring the EFP mechanism, a refiner can sell the purchase of a short futures contract to cover his expected futures surplus. As of May 1980 , 561 EFPs have been completed, the majority of them in the first few months of 1979.

\section{Futures Prices}

The prices of No. 2 futures contracts, like the No. 2 spot prices, reflect normal seasonal variations, expectations of future prices and supply, and general economic conditions. Typically, fuel oil prices reach their annual low point during the late spring and early summer, when heating needs are minimal, and are generally at their height at the beginning of the winter heating season -October and November. This price trend is shown in Exhibit 9.

As demonstrated during the 18-month existence of the futures market in No. 2 oil, futures prices and spot prices generally follow the same seasonal patterns. However, in volatile markets such as those we have seen lately, expectations of future price movements and supply availability dominate. Moreover, these expectations tend to be reflected in futures contract prices before the spot market reacts to them. Of course, as the expiration date of the futures contract nears, the futures and spot prices converge. Exhibits 10, 11, and 12 show May 1979, November 1979, and January 1980 futures activity relative to the spot market.

Over the 18-month history of the No. 2 oil futures market, the product prices have been particularly volatile. For example, New York Harbor spot and delivered prices for No: 2 oil doubled from less than 45 per galion in November 1978 to over $\$ 1.00$ per gallon by June 1979, counter to the usual seasonal pattern. This dramatic price movement was caused by the onset of the Iranian revolution and the attendant concerns about crude oil supplies. In addition, the gasoline shortage that 
Exhibit 9

Weekly New York Harbor Spot Prices and Delivery Prices of No. 2 Oit

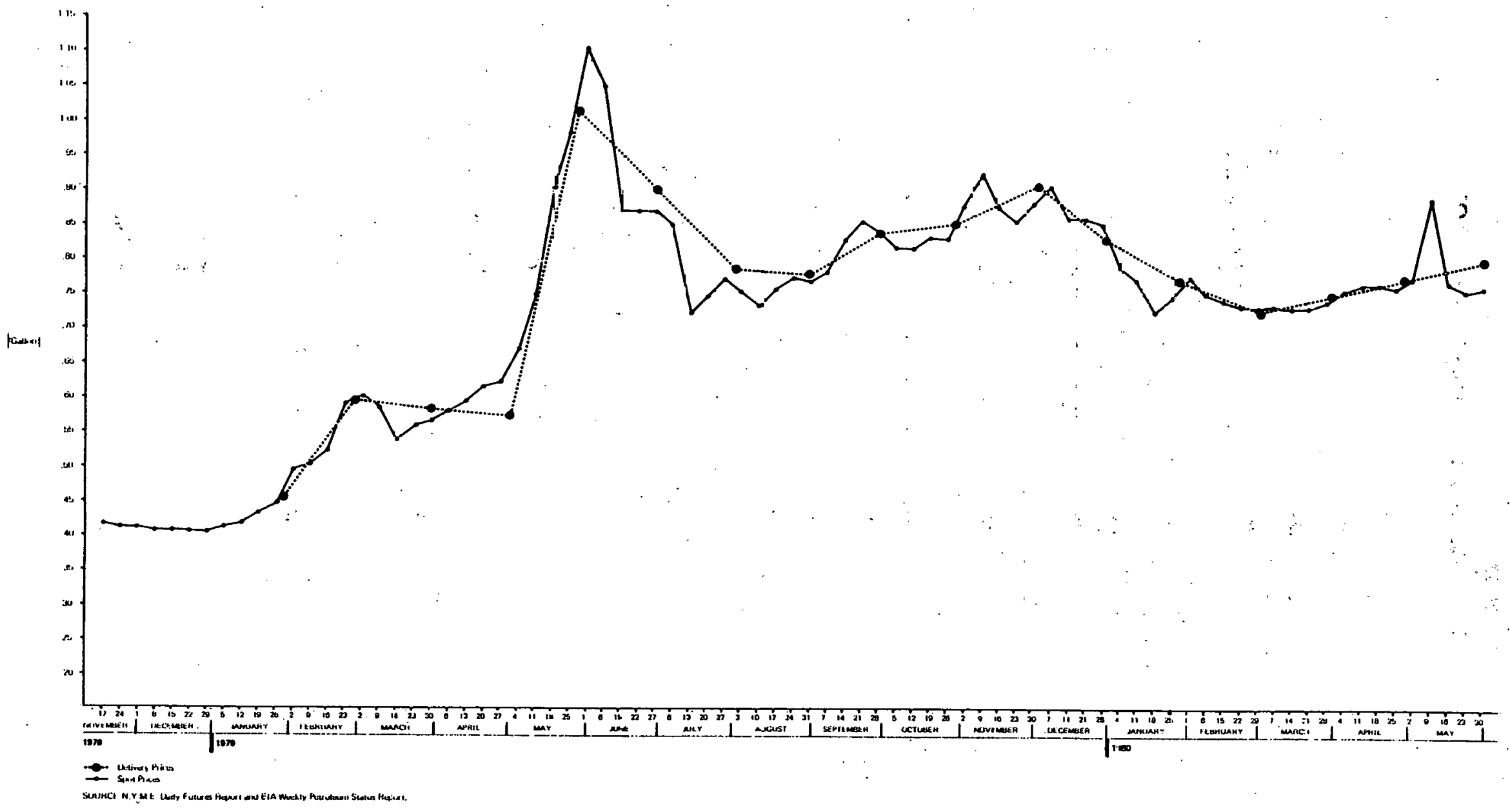


Exhibit 10

Market Activity of the May 1979 No. 2 Oil Contract

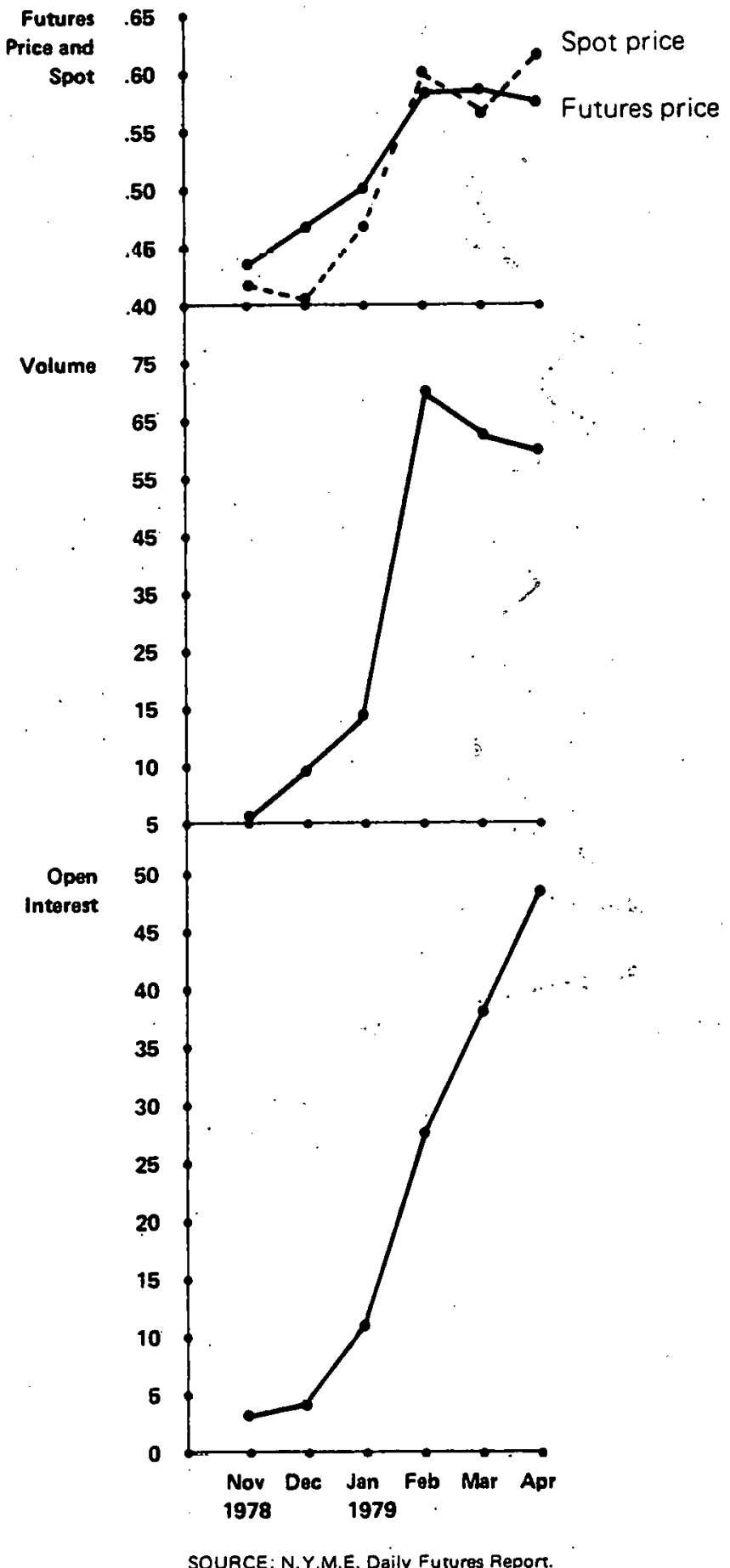


Exhibit 11

Market Activity of the November 1979 No. 2 Oil Contract

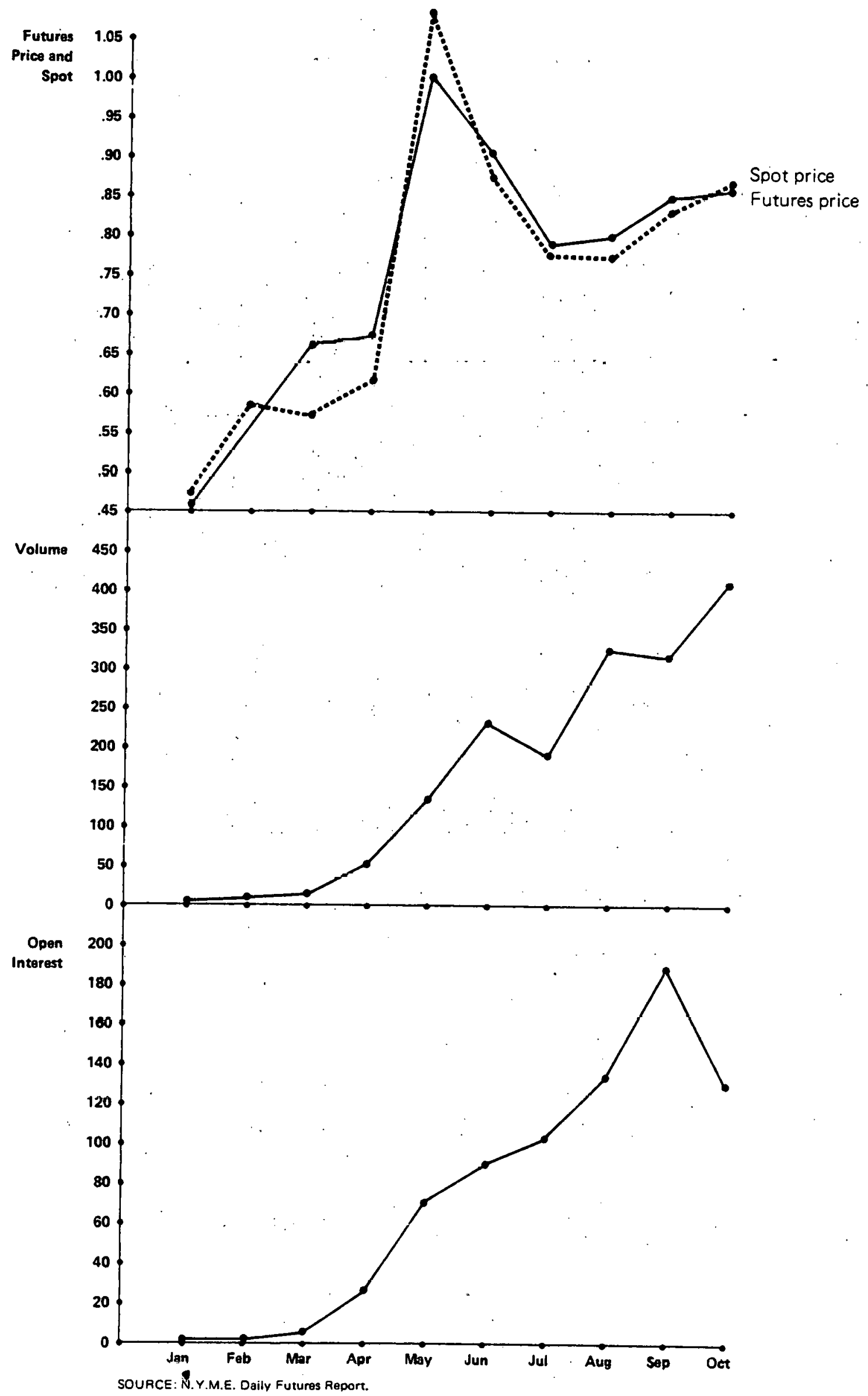


Exhibit 12

Market Activity of the January 1980 No. 2 Oil Contract

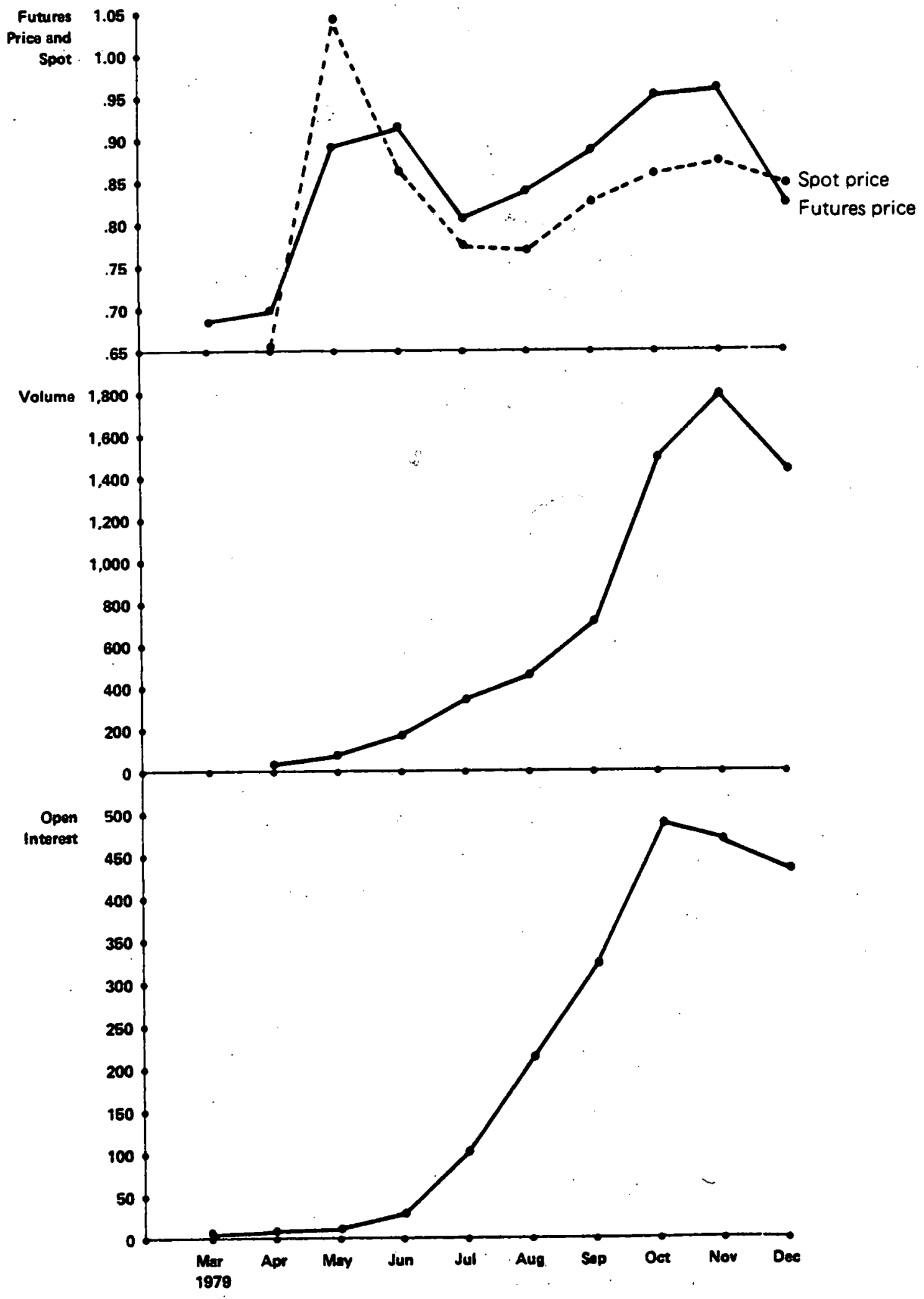

SOURCE: N.Y.M.E. Daily Futures Report. 
occurred in the northeast and the west in the late spring and early summer of 1979 prompted refiners to increase their runs of gasoline at the expense of distillate fuel oil. As fears about supply shortages eased and gasoline use decreased -- due to the combined effects of conservation and higher prices -- both inventories and refinery output of fuel oil increased. Consequently, spot prices for No. 2 oil fell slightly. By the summer of 1979, spot prices decreased to about $80 \notin$ per gallon.

Owing to the significant "overhang" of No. 2 oil and an unseasonally mild winter, wholesale demand for home heating oil during the 1979-1980 winter was significantly less than normal. By the beginning of November, total U.S. No. 2 oil stocks stood at 245.9 million barrels, compared with 233.2 million barrels in November 1978. Consequently, spot prices for No. 2 reached $95 \not$ per gallon in late November and fell to about $75 \not$ per galion in early January 1980. Since that time, "spot prices have reflected normal seasonal patterns,prior to the annual summer fill. In March 1980, spot prices were $75 \not$ per gallon.

In November 1978, futures contract prices for a May 1979 commitment traded for about $42 \not$ per galion up 17 percent from the May 1978 spot prices of $36 \not$ per galion. By January 1979, futures prices for the May 1979 commitment were about $50 \notin$ per galion, up 39 percent from the May 1978 spot price. (Exhibit 10 shows price, volume, and open interest for the May 1979 commitment.)

In early March of 1979, however, futures contract prices began to reflect investor fears about the price and supply repercussions of the Iranian crisis. By May and June, the futures prices reflected investor concerns about inadequate inventory. In January 1979, for example, futures contract prices for a November 1979 commitment were $45.75 \not$ per gallon; in March, the futures price was $67 \not$ per gallon; and by May, the price was $\$ 1.0125$ per gallon. (Exhibit 11 shows price, volume, and open interest for the November 1979 commitment.)

By June 1979, stocks of No. 2 oil began to increase, while concern about possible dire consequences of the Iranian crisis eased. These changes were reflected in futures prices, which dropped sharply between June and August. In June 1979, for example, the price of a January 1980 commitment was $92.25 \notin$ per gallon, while by August, the price had fallen to $83.50 \notin$ per gallon. 
During September, October, and November of 1979 , futures prices began to climb, following normal seasonal patterns and reflecting general inflationary trends. By December 1979, however, futures prices began to drop, owing to the milder-than-normal winter and the large inventory.

Since the spring of 1980, futures prices, like spot prices, have begun their seasonal upward climb, spurred by double-digit inflation.

Futures trading in No. 2 oil also has evidenced some price dampening effects. The relationships between spot and futures prices shown in Exhibits 10,11 , and 12 indicate that futures prices fluctuate slightly less than spot prices. However, more experience with futures trading in No. 2 oil is needed to justifiably assert that the No. 2 futures market exerts a moderating influence on prices.

Safeguards Against Collusion, Fraud, and Price Fixing

The NYME exists to ensure that the trading process is open, fair, and orderly. To accomplish this, the NYME has established a number of regulations affecting price movements, brokers, quality of product, and delivery. It operates under the direction of the commodity Futures Trading Commission (CFTC), which makes sure that the NYME enforces its own rules. Under such scrutiny, it is difficult for market participants to manipulate the futures market.

At present, there is little danger of market manipulation. The futures market in No. 2 oil is relatively thin, and the volume of oil traded there is but a fraction of the product bought and sold on the east coast. Thus, anyone attempting to manipulate the market would have to purchase millions of dollars of futures contracts which would be difficult to keep secret from the oil trading community as the futures price would rise well above the cash market. In addition, with trades cleared daily through the NYME's clearinghouse, detection of such action would be simple and rapid.

All bids and offers are made verbally, so that everyone on the auction floor has an equal opportunity to obtain 
the best possible prices. The NYME requires that a market order* be executed at the best price available to the broker as soon as he receives it from the account representative. If the order is a limit order, $* *$ the broker must wait until the market reaches the appropriate level before executing it. When the trade is executed, the information goes into the clearinghouse's computer system. The clearinghouse assigns each trade to the appropriate clearing member and pays and collects margin and price variation changes each day.

To ensure that price manipulation does not occur, the NYME also has imposed ceilings and floors on daily price movements. For example, the minimum price fluctuation for No. 2 oil is $0.01 \%$ per gallon. The maximum price fluctuation is $2 \notin$ per gallon on the first two limit days: $3 \notin$ per gallon on the third day; and $4 \not$ per galion thereafter.

The NYME has taken several steps to ensure that the delivery of product, if desired, is orderly. The NYME operates a clearinghouse that monitors trading and deliveries. The clearinghouse must act to ensure that all products delivered meet"contract specifications. It must also ascertain that the product is properly certified and delivered by the seller, and then paid for by the buyer at the right time and place. To accomplish this, the clearinghouse management assists in the selection, approval, and supervision of commodity inspectors, certifying agents, warehouses, and depositories. Additionally, the NYME has established the EFP mechanism to permit the private negotiation of, among other things, contract delivery terms.

$$
\text { C }
$$

* A market order' is to be filled promptly at the best price the broker can obtain.

* Under a limit order, the customer instructs the broker to "buy but pay no more than" or "sell but take no less than," and while he is thus assured that he will get at least the price he wants if the order is filled, he runs the risk of not getting the order filled. 
Prospects for No. 20 ol Trading

Even the brief experience with the No. 2 oil futures market has demonstrated that an appropriately regulated futures market has the potential to function as a complementary pricing system to the cash market. Indeed, the futures pricing mechanism further contributes to price stability by providing information to the trade. Even if businessmen do not take long or short positions in the market themselves, the information helps them to make more efficient decisions on inventory, production, and consumption.

There are already plans to extend futures trading in No. 2 oil to the Gulf Coast. The Chicago Board of Trade has applied to the CFTC for permission to trade a No. 2 oil contract for delivery on the Gulf coast. In addition, the NYME has a No. 2 Gulf Coast delivery application pending before the CFTC, in addition to a contract for leaded and unleaded regular.gasoline. In expanding product trading in the United States, much can be learned from the disappointing experience with Rotterdam futures markets in gasoil and bunker fuels (the equivalent of U.S. No. 2 and No. 6 oils), which failed to meet the needs of U.S. participants. Very few contracts were ever traded in the Rotterdam contract, principally because trading occurred in New. York, but delivery was required at Rotterdam. Product specification differences between Rotterdam contracts and the needs of U.S. market participants also dampened trading interest.

To expand futures trading in No. 2 oil, commodity specialists at a number of leading brokerage houses are promoting a strategy that will tie No. 2 oil contracts to spot and futures prices. The plan -- supported by Merrill Lynch, Shearson Loeb Rhodes, and E.F. Hutton - is an attempt to wean dealers away from the posted prices of the major refining companies.

The strategy for No. 2 oil is similar to the pricing systems in other commodities. Ten years ago, for example, copper contracts were based on producers'. postings; now, most of the industry has switched to pricing contracts on the spot and futures markets. In ressence, the scheme would allow the futures market in No. 2 oil to. function as a pricing system complementary to the cash market. 
Under such a pricing strategy, the user's oil dealer would agree to deliver the product on a future date at the spot market price on that day, plus the traditional dealer markup of 9-15 cents a galion. At the same time, the user would purchase an equal amount of oil with futures contracts that are due to expire on delivery day: By hedging, the user will: have locked in the price he will pay for oil when 1 t is delivered.

Proponents of the plan suggest that it would lead to greater competition in the industry because it encourages dealers to compete on margins. Under current supplier/ purchaser regulations, the user is tied to his dealer, who passes along the major oil companies' posted prices. 'The dealer has no incentive to compete because his supplies are mandated by DOE-imposed allocation regulations.

The acceptance of this concept is hampered by the fact that the NYME's futures market in No. 2 oil is still too thin to permit large volume trades (i.e., 100-200 contracts at a time). However, traders hope that plans by the Chicago Board of Trade to initiate trading in No. 2 oil will double the volume on the contract.

In addition, the problems that the NYME has experienced in deliveries on other commodity contracts are dampening the growth of the No. 2 Eutures market.* For example, in 1976 a large potato trader defaulted on contracts because another group of traders allegedly cornered the market. Three years later, a blight hit the Maine potato crop, causing thousands of NYME potato contracts to be defaulted.

* A fraudulent scheme involving oil contracts by promoters in New York; 'Houston, and other cities also made investors skeptical of futures trading. In this scheme, which occurred in early 1.980, promoters sold bogus oil contracts to unwitting investors. These contracts were not backed up by any oil and were not associated with any exchange. The scheme was uncovered and indictments have been issued. 
OTHER PETROLEUM FUTURES MARKETS

Having examined the characteristics of the growing futures market in No. 2 oil, we next assessed the reasons for the failure of the No. 6 oil futures market and the likelihood of futures markets developing for other"petroleum products - gasoline, jet fuel, and crude oil: In the following sections, we present the results of our assessment.

No. 6 . Residual Fuel

Oil Market. :

The NYME has already attempted to develop a futures market for No. 6 residual fuel oil. Under the contract, which is similar to that for No. 2 oil, New York Harbor delivery and New York City quality specifications are required. The contract has failed, for three reasons:

First, the No. 6 market does not have as many buyers and sellers as the market for No. 2 oil. A much larger proportion of. No. 6 oil is sold by large refiners or their distribution cuboidiaries directly lo edst cuast electric utilities than is the case with No. 2' oil.* Some of the large jobbers handle No. 6 and market it to utilities, but primarily, through direct negotiation or, in the case of most municipalities, through bidding. In contrast, most No. 2 oil is sold through jobbers, of whom there are 15,000 to 18,000 in the United States. The No. 6 oil spot market also differs from No. 2 oil spot market in that No. 6 oil market participants already have information on market transactions. Thus, they do not require the expansion of contacts that an organized exchange market can stimulate.

The second and apparently more important reason for the lack of success in trading No. 6 oil futures is the widening price differential between high- and low-sulfur material. New York City specifications on No: 6 oil

* In 1978, the nation's electric utilities consumed 72.7 million, barrels of No. 2 oil and 33.2 million barrels of No. 6 oil. In the northeast, electric utilities consumed 16.2 million barrels of No. 2 oil and 23.7 million barrels of No. 6 oil. 
sulfur content call for a maximum of 0.3 percent, while in most eastern states the sulfur restrictions run as high as 2.8 percent. Consequently, a utility in Connecticut, for example, need not pay as much for the higher-sulfur No. 6 oil as iis counterpart in the New York area must pay for the lower-sulfur product. As long as the price relationship between high- and low-sulfur No. 6 oil.was retained, with one price above the other but both moving in the same direction, the buyer of the high-sulfur material could hedge by purchasing futures in the low-sulfur material.

For the past 2 years, however, the prices of high- and low-sulfur No. 6 oll have been moving in opposite directions. 'Ihe scarclty of highwquality, low-sulfur crude oils in the world market has put a premium on low-sulfur No. 6 oil which today selis for as much as $\$ 30-\$ 40$ per bbl. On the other hand, high-sulfur No. 6 oil, made either from low-quality, high-sulfur crude oil or as the byproduct of certain refining processes, has been selling for as low as $\$ 14$ per bbl." The disparate price movements of high- and low-sulfur No. 6 oil have invalidated the futures trading concept of a consistent price basis. Thus, there has been Iittle or no interest in the NYME's No. 6 oil futures contract on the part of utilities in New England, New Jersey, Pennsylvania, and other states that permit the burning of a higher-sulfur RFO than New York City.

The problem of differing fuel quality might be resolved by opening several new No. 6 oil futures contracts to account for the higher-sulfur material. In addition, such market exchange devices as the trading of warehouse receipts against a fixed set of terminals containing a given level of No. 6 oil sulfur. content might be employed. Finally, geographic areas, such as the midwest, that feature a more uniform set of No. 6 oil sulfur specifications might be tried; a No: 6 oil futures contract with Chicago delivery, for instance, could be successful for market participants in that region of the country.

The third barrier -- and in our judgment the most serious', - - to the acceptance of futures trading in No. 6 oil is the existence of the fuel adjustment clause for oil purchased by utilities. Public utility commissions across the country have permitted utilities to pass through to their customers the full increase in their 
fuel costs, in most cases on an automatic basis. As a result, the utility purchasing agent has little incentive to try new, approaches to reducing the utility's fuel costs. In fact, utility purchasing executives have cited the lack of incentive when responding to brokers' inquiries on the use of an oil futures market.

The Public Utility Regulatory Policy Act (PURPA) legislation, which requires utilities and state public utility commissions to examine new fuel procurement methods, could be used to break down the barrier to No. 6 oil futures trading. Industry experts have recommended that the impact of automatic fuel escalation passthrough procedures on utility fuel costs be reviewed. If some states, for example, were to limit the use of the automatic fuel adjustment clause as a result of the PURPA legislation, the prospects for a No. 6 oil futures market might be enhanced. In addition, a number of state courts have already ruled that the fuel clause adjustment system may be illegal or unenforceable, putting added pressure on some state legislatures to change the system.

While a futures market for No. 6 oil may be unworkable at the present time, we think that other organized exchange systems might well be explored by the utility industry. In the short term, utilities have some flexibility owing to their multiple-fuel-burning capacity. An exchange system for utility fuels (oil, gas, and coal) could provide valuable information on the fuels market for the purchaser. Knowing which fuels are available, and from whom, at future points in time, and knowing whether these fuels can be transported, traded for money, or exchanged as future supplies are important elements of a possible utility industrywide fuel information system. To provide information on fuels, a real-time information bank could be established. The bank wo bild enable subscribing utility purchasers and supplying companies to enter price and quantity information via computer terminals. Although such measures do not lead directly to a new pricing mechanism; they do increase market knowledge, thereby effectively enhancing the buyer's range of choice. Ultimately, an information system might engender a different pricing relationship, and in so doing, expand market competition and permit utilities somewhat greater market leverage than they now possess. 
Motor Gasoline

Both the NYME and the Chicago Board of Trade have announced plans to open wholesale gasoline futures markets, presumably when the current gasoline price controls expire in October 1981. In fact, the NYME has already submitted for CFTC approval two gasoline contracts -- one for unleaded and one for leaded regular gasoline, and both designated for New York Harbor delivery. In light of its reasonable success in the No. 2 oil contract, the NYME is hopeful that its gasoline contracts will be well received by both oil industry and large end-users.

Compared with other petroleum products, the motor gasoline market is immense. The average daily consumption of middle distillates is $3 \mathrm{mmb} / \mathrm{d}$; that of motor gasoline is $7 \mathrm{mmb} / \mathrm{d}$. The market for gasoline is highly seasonal, with peaks in consumption occurring in late spring, summer, and early fall, and troughs occurring in the winter months. As refiners and distributors stock up for peak demand and then run down their inventories as winter approaches, a wide inventory swing occurs. As a result, the cost of holding inventory is an important factor in profitability. In addition, price fluctuations at the wholesale level have become more pronounced in recent years, even with controls (or perhaps, in part, as a result of the price control system). When gasoline price controls expire, existing spot market participants expect a major expansion in gasoline trading, largely because of increasing supply and price uncertainties. As the major oil-refining companies grow increasingly vulnerable to a changing mix of crude oil, the variation in wholesale gasoline prices among different companies is also likely to increase.

In the motor gasoline market, as in that for No.. 2 oil but in contrast to that for No. 6 oil, quality differential problems do not appear to be significant.

New York City gasoline specifications are substantially the same as those used throughout the country. In addition, transportation differentials appear to be uniform, allowing the oil industry and end-use hedgers to establish a consistent price bas is between regions of the country. Owing to these factors, the gasoline market appears to satisfy some of the main criteria for successful futures trading. 
In our view, the only significant barrier to the development of a successful gasoline futures market could be the lack of sufficient storage capacity. According to published figures, between 6 weeks' and 2 months' supply of gasoline can be stored nationwide, in contrast with the country's grain storage capacity, which equals a full year's consumption. The limited capacity for storing gasoline could cause delivery problems in peak trading months should a large number of contract holders opt for actual delivery. These problems could be dealt with, however, by expanding storage capacity, leasing existing storage now utilized by certain end-users, and making minor changes in the delivery mechanism.

\section{Jet Fuel}

Jet fuel, at the lighter end of the distillate group of petroleum products, is in fact a type of kerosene. For this reason, there is a reasonably close correlation between the price of No. 2 oil and that of jet fuel. Although some airlines have expressed an interest in using the No. 2 oil futures market to hedge their jet fuel costs, we are not aware that any have actually done so as yet.

Because jet fuel is manufactured for a very specific market, it has only a limited number of end-use customers, compared with the users of gasoline and No. 2 oil. In addition, the major refiners typically sell jet fuel directly to the airlines on a long-term contract basis. Many refiners also supply ancillary services, such as specially designed tank trucks, pumping equipment, and lubes and greases. It is not a market, therefore, that sees much spot trading activity, except during temporary periods of extreme scarcity.

The demand for jet fuel is not particularly seasonal, because the increase in passenger transit loads that airlines typically experience in the summer does not substantially affect the number of flights and therefore fuel consumption. Although jet fuel demand is sensitive to business cycle fluctuations, it is not as volatile as other fuels and thus does not necessitate major inventory shifts. Because there is not great latitude for reducing or increasing jet fuel yields, the refiner's financial 
incentive to manufacture more fuel, or less, is related to his relative profitability in gasoline and distillates. Jet fuel consumption is only $1 \mathrm{mmb} / \mathrm{d}$, compared with 7 $\mathrm{mmb} / \mathrm{d}$ for gasoline and $3 \mathrm{mmb} / \mathrm{d}$ for distillates. As a result, jet fuel prices are related to these other, larger markets.

On balance, therefore, it is unlikely that a jet fuel futures market would be viable, since there are few buyers and sellers and pricing is tied to gasoline and middle distillate markets. Nevertheless, as in the case of utilities and residual fuel oil, new jet fuel exchange systems could be developed for the airline industry, should it so desire.

Potential for Futures

Markets in Crude Oil

An organized exchange market for crude oil operating on an international scale might be in the best interests of all market participants. Such an exchange system would perhaps be a better mechanism for determining the price of oil than an international treaty based on political perceptions of a "fair price." In light of the virtually impossible task of obtaining a consensus on what constitutes a "fair price," appropriately regulated exchange markets would offer the best mechanism for letting all buyers and sellers vote on the price that they consider "fair."

The replacement cost of synthetic energy sources is not a realistic basis for crude oil pricing, because it implies that price is determined by supply and influenced little, if at all, by demand. In fact, as crude oil is an internationaliy traded commodity, its price is often strongly influenced by demand factors. Nor is the indexing of oil prices to world inflation a useful departure point for international negotiations on a "fair price." General economic inflation hurts oil-consuming and oil-producing countries alike. If the oil-exporting countries continue to increase the price of a barrel of oil to offset their loss of purchasing power, inflationary pressures in such countries are compounded; causing the price of the world's non-oil goods and services to rise even higher. An appropriately regulated market exchange system, however, would not permit any one group of buyers or sellers to employ excessive market leverage. 
Unfortunately, the simple principle whereby prices rise when there are more buyers than sellers, and prices fall when there are more sellers than buyers, does not apply in today's crude oil markets. This is due in part to domestic crude oil price regulations, and in part to the pricing policies of OPEC. By developing approaches to an effective crude oil exchange system, however, U.S. government policy could promote the greater ise. of the free market mechanism in both domestic and international markets. Properly regulated to prevent both monopolistic and monopsonistic practices, such a market would reflect the true value of a barrel of oil at any point in time.

Commodity futures markets operate effectively in certain agricultural and metal raw materials as well as in the infant No. 2 oil market. The absence of a futures market for crude oil, however, can be explained by historical, organizational, and technological reasons. Historically, crude oil markets were largely controlled by refining interests; that is, prices were primarily dictated by buyers who had the ability to turn crude petroleum into useful products. Market dominance stemmed from the ability to satisfy a growing number of uses for petroleum products, with the coming of the automobile age, the electrification of industrial economies, and more recently the growth of air travel and the petrochemicals industry. As far back as the turn of the century, the dominance of the Standard Oil Trust was largely a reflection of the drive by the refining and marketing segments of the oil business to obtain secure sources of raw material. In the United States, the historical control of pipelines from the oil fields gave the crude oil buyer the physical ability to dictate prices. Overseas, it was the refining interests themselves who either discovered the crude oil reserves, or quickly bought out the independent concessionaire who might have discovered a major pool of oil.

As a result of vertical integration and the provision of an assured market for the growing volume of crude oil, there was no incentive for the industry to develop a futures market. Large pools of oil were discovered from time to time, but these remained primarily in the hands of those who had their own refining and marketing outlets. In the United States, where there was (and still is) a substantial number of independent oil companies on both 
sides of the crude oil market, futures pricing never developed because the vertically integrated major oil companies provided both a stable outlet for the crude seller and a stable supply source for the independent refiner. In fact, after the discovery of oil in East Texas in the early 1930s, the market became so glutted that the state of Texas imposed a system of "market demand prorationing," which limited production of crude oil to those volumes that the major refining companies wished to purchase. In this way, the U.S. crude oil market was effectively. insulated from significant price pressures in the product market. Overseas, the same type of market stability was achieved through agreements among major oil companies. to divide up the international markets.

These agreements were often sanctioned by the European governments that did not oppose cartels in the way that the United States did.

There are other reasons why a crude oil futures market never developed. First, there were not enough independent participants. Second, the time required from the production of crude oil from known reservoirs to the consumption of the crude oil in the refinery was not long enough to impose unacceptable risk's on buyer and seller. In copper production and in agriculture, the uncertainties imposed by long lead times is one major reason why futures markets have developed. The long lead times in the oil business occur in the exploration and development phase, prior to the installation of producing capacity.

Nevertheless, because a greater degree of control of the crude oil market has now, shifted to the producing countries, there may be a cáse for the development of an international crude oil futures market. Technical problems abound, however, such as quality differentials among crude oils that cannot be easliy transferred from one refinery to another. The existence of sufficient storage capacity at particular distribution centers is another problem. Most importantly, under present pricing practices, there is not enough fluctuation in the price to justify a full-fledged futures market at the present time. The OPEC takeover of the pricing mechanism, coupled with producer country ownership of the crude oil itself, may gradually require new international market mechanisms with a much greater degree of arm's-length 
bargaining between crude oil seller and purchaser. On the domestic side, decontrol of crude oil prices may cause greater price fluctuation and thus provide an incentive to private market participants to pass on risk through the use of futures markets. Finally, as more independent crude oil sources develop over the next several years, both buying and selling interests in the crude oil market may well turn to an organized exchange mechanism for pricing.

Domestic crude Oil

In the U.S. oil industry, literally hundreds of firms -including large and small refiners, crude oil gathering companies, and pure traders - actively trade crude oil. The trading; which is promoted primarily by geographic, timing, and quality differentials, is entirely a spot market, with mainly month-to-month contracts. Refiners constantly search for types of crude oil that will best satisfy their product slate. Major companies maintain their own crude oil trading staffs, while the smaller refiners often employ professional crude oil trading firms. Crude oil gathering companies typically serve the hundreds of independent producers, maintaining a combination of field pipelines, terminals, and trucks to gather the oil and transport it to. larger pipelines or directly to refineries. Major oil-producing basins such as the Permian and Anadarko regions have a number of these crude oil gathering firms serving the thousands of wells in those areas.

Pure crude oil traders, operating between crude oil gathering firms and smalier refiners or crude oil pipeline companies, essentially perform a classic market-making function in crude oil. They will assemble a mix of different quality crude oils for refinery clients directly, or for other traders who will deal with the refiners. They secure the crude oil from independent producers, gathering firms, and large oil companies. Each month, a vast number of trades occurs to perform this complex matching process.*

* In December of 1979, a large group of these traders testified before DOE's Economic Regulatory Administration on their activities. 
Because of this trading network, a framework exists for the development of an organized crude oil exchange system. Such a system is not likely to function, however, in the manner of a conventional futures market with a standardized product. Approximately 100 different types of crude oil are produced in the United States alone, characterized largely by the producing regions from which they come. Certain crude oils yield a greater proportion of gasoline and petrochemical feedstocks with the same refining processes; other crudes may be better suited for the middle distillates or heavier petroleum products. Refining technology can upgrade most crude oils, but the processes are complex and expensive. As a result, a given refinery configuration ( $i . e .$, level of processing technology) will require a changing mix of crude oils, depending on the changing petroleum product requirements that the refiner seeks to meet. Any attempt to organize an exchange market for crude oil will have to accommodate these major quality differentials.

An important index of quality differential is the socalled. API gravity number. The higher the number, the "lighter" the crude and the more likely it is to contain less sulfur and other impurities. In addition, natural gas 1 iquids tend to be of very high quality and form an important part of the refinery feedstock stream. In theory, it would be possible to specify a crude futures contract with a minimum API gravity level. For example, natural gas liquids and all crudes at or above $34^{\circ} \mathrm{API}$ could form the highest-quality crude oil contract. Heavier crudes -- those with lower API gravity levels -could be traded against this basis, provided the pricing fluctuations were consistent.

In practice, it is unlikely that price differentials will remain consistent, as indicated by the failure of the No. 6 oil futures market. Prices for heavier crude oils, such as those at $25^{\circ}$ API gravity and below, may well stabilize or even decline, while the lighter crude oils will increase in price. Crudes with API gravities in the $26^{\circ}-34^{\circ}$ range could go in either direction, depending on other quality characteristics. A single futures contract would thus be unlikely to satisfy the needs of the existing crude oil trading community. Several crude oil futures contracts could be developed, using the API gravity index as the primary criterion. But then the other quality differential criteria would be likely to come into 
play, crucially affecting the price-setting mechanism. As a result, crude oils of the same gravity could contain different quantities of sulfur, mineral impurities, or other quality differentials that would make one of the crude oils much more valuable than another.

A crude oil contract was developed by the New York Cotton Exchange. In the contract (a summary of which is provided in Exhibit 13), trading is based on $34^{\circ}$ API, 1.7percent sulfur, with the seller having the option of delivering crude oil inferior or superior. The failure of the Cotton Exchange's crude contract was due to a lack of attention to industry trade practices, such as quality differentials, shipping schedules, and delivery terms.

One solution to the problem of quality differentials is to make no attempt to standardize them. In such a case, brokers on the floor of a crude oil exchange would negotiate each deal separately, as they now do in the domestic spot market for crude oil. The brokers could act either as agents taking a commission, or as principals for their own accounts. Such a form of trading would also widen the market for all participants as a result of the informationgenerating function of an exchange floor. Each trade could still be recorded on an open tape, with some added information on the quality of crude being traded. Although such a system is not typical of the existing commodity exchanges, it could be designed to satisfy most CFTC rules. While not particularly appealing to the public speculator, it might offer the private hedger price protection and access to new supplies.

International Crude Oil

The decontrol of U.S. crude oil in October of 1981 may prompt the development of a vast, worldwide crude oil market. * Before any exchange market system could be developed, with either spot or futures pricing, however, the interests of all participants, including private oil companies, national oil companies of producing and consuming countries, and a growing number of crude oil trading firms, would have to be accommodated. No single group could develop such a market alone. ',

* Canadian price controls will remain in effect for Canadian consumption, but not for exports. 


\section{Exhibit 13}

Summary of Crude Oil Futures Contract Terms

(New York Cotton Exchange)

Contract. Unit:

Delivery Point:

Price Quotation:

Minimum Price Fluctuation:

Maximum Daily Price Limit:

Contract months:

\section{Produot Spcoifiontions}

Gravlty:

Sulfur:

Water and Sediment:

Pour Point:

Salt:
5,000 barrels

New York Harbor

Dollars and cents per gallon

$\$ 0.0001(0.1)$ ) per barrel

$\$ 0.25(.254)$ per barrel (No limit un last trading day of month preceeding dellvery)

March, June, September, December

Amerlcan Petróleum Institute 450. maximum, 270 minimum

$3 \%$ maximum, $0.1 \%$ minimum

$1.0 \%$ maximum

3,000 metric tons per hour minimum

25 pounds per 1,000 barrels maximum

SOURCE: New York Cotton Exchange. 
Some multinational oil companies might favor the growth of such an international crude oil exchange system. In particular, the companies without preferred access to major crude oil sources are likely to view an open market system somewhat more favorably than those private oil companies that retain access to lower-priced and secure sources of crude oil.* Because such an exchange system would offer ready and open access to all buyers and sellers, those companies with preferential access would find it more difficult to maintain their competitive advantage. In addition, other, non-oil, business relationships between certain multinational and the governments of some oilproducing countries might become somewhat more difficult. Finally; the tax implications for certain multinationals might be negative, as greater visibility would be given to the actual transfer price between crude oil production and refining. Nevertheless, as the governments of the oilexporting nations continue to move away from the preferential access system, the multinational companies that would be most affected by such an exchange market system may gradually reduce their opposition to it.

The governments of the oil-exporting nations, or, more particularly, the state-owned oil companies that are involved in the day-to-day management of the country's oil resources, might see certain advantages. in the development of a crude oil market exchange system. In brief, such a system would provide them with a greater range of selling opportunities, immediate and totally visible prices, and the ability to hedge their own inventories and other risks. These companies could continue to conduct their operations as they do now; their rapid access to information on the state of the oil market, however, would enable them to respond more rapidly to changing market conditions.

On the other hand, a crude oil market exchange system has the potential to challenge OPEC's control of world crude oil prices. To control the market exchange price, more formal volume controls might have to be instituted by

* This is borne out by the aggressive role that British Petroleum (BP), which is short of crude supplies because of the Iranian crisis, appears to be taking in the development of a London-based futures contract. 
OPEC, a mechanism that the member governments have so far resisted. Nonetheless, as the pressures within OPEC grow because of economic and political rivalries, a market exchange system might appear to be to their mutual benefit. Under such a system, each sovereign nation could continue to make its own production decisions and continue to choose, at its discretion, whether to sell oil at the market price. The governments of these nations might well encourage a market exchange system if they had a role in the system's development.

Surprisingly, it may be more difficult to convince the governments of oil-consuming nations of the merit of an exchange system. One barrier to the acceptance of a crude oil market exchange system by these governments is the perception of commodity markets as a potential source of manipulation and even fraud. Another, more serious barrier to acceptance could stem from differing regulatory approaches among the major oil-consuming countries. On balance, however, the governments of oil-consuming nations are likely to prefer; a market-determined pricing system to the present pricing methods.

In our opinion, if the political impetus to develop such a system exists, or can be created, the technical issues of contract specifications, delivery mechanisms, default penalties, and payment terms can be accommodated. The germ of such impetus can be seen, for instance, in the likely involvement of some European governments in the creation of the new London Commodity Exchange gasoil contract. In this way, experience can be gained over time to guide the evolution of an international system.

\section{Summary}

Significant potential exists for the development and growth of petroleum futures markets. Currently, only the futures market in No. 2 oil' is active. "It is used primarily by jobbers, distributors, and oil traders. The No. 2 oil futures market is successful because it satisfies four of the most important criteria for a viable futures market: a large number of buyers and sellers; a degree of price volatility; adequate storage; and product homogeneity. Moreover, there are no federal controls on No. 2 prices and allocation. 
Under certain circumstances, viable futures could be developed in crude oil and gasoline, provided that decontrol is a prerequisite. Gasoline and crude oil satisfy important criteria for functioning futures markets. Each has a large number of potential participants and a degree of price volatility. Storage does pose a problem; for example, there is inadequate storage for gasoline and crude oil in New York Harbor. With its standardized grades, gasoline satisfies the criterion of product homogeneity, or a consistent price basis. Therefore, a crude oil futures contract must take into account the many quality differentials. (Exhibit 14 shows how various products match up against these criteria.)

In contrast, a futures market in No. 6 oil, which has been unsuccessful, and jet fuel, have little potential, principally because of the small number of buyers and sellers for each product.

Based on recent experience with the futures market in No. 2 oil, as well as the long history of other commodities futures trading, we concluded there are significant benefits and only IImited costs to expended petroleum futures market development. As suggested by the performance of the No. 2 oil futures market, petroleum futures markets can have important impacts on price and supply mechanisms, industry competition;, and may reduce the burden of regulation.

If petroleum futures markets grow, private-sector storage in the northeast could increase. An appropriately regulated futures market has the potential to function as a complementary pricing system to the spot market. The prices of No. 2 futures contracts reflect normal seasonal variations, expectations of future prices and supply, and general economic conditions. Moreover, the brief experience with the No. 2 oil market indicates that futures trading may have some price-dampening effects. The futures pricing mechanism further contributes to price stability by providing information to buyers and sellers. This timely and easy access to information helps firms (and individuals) in the industry make more efficient decisions on inventory, production, and consumption. The existence of surplus product. can be quickly communicated and translated into lower product prices. Such an open and visible pricing mechanism can make the petroleum industry more competitive. 
Futures Market Potential for Petroleum Products

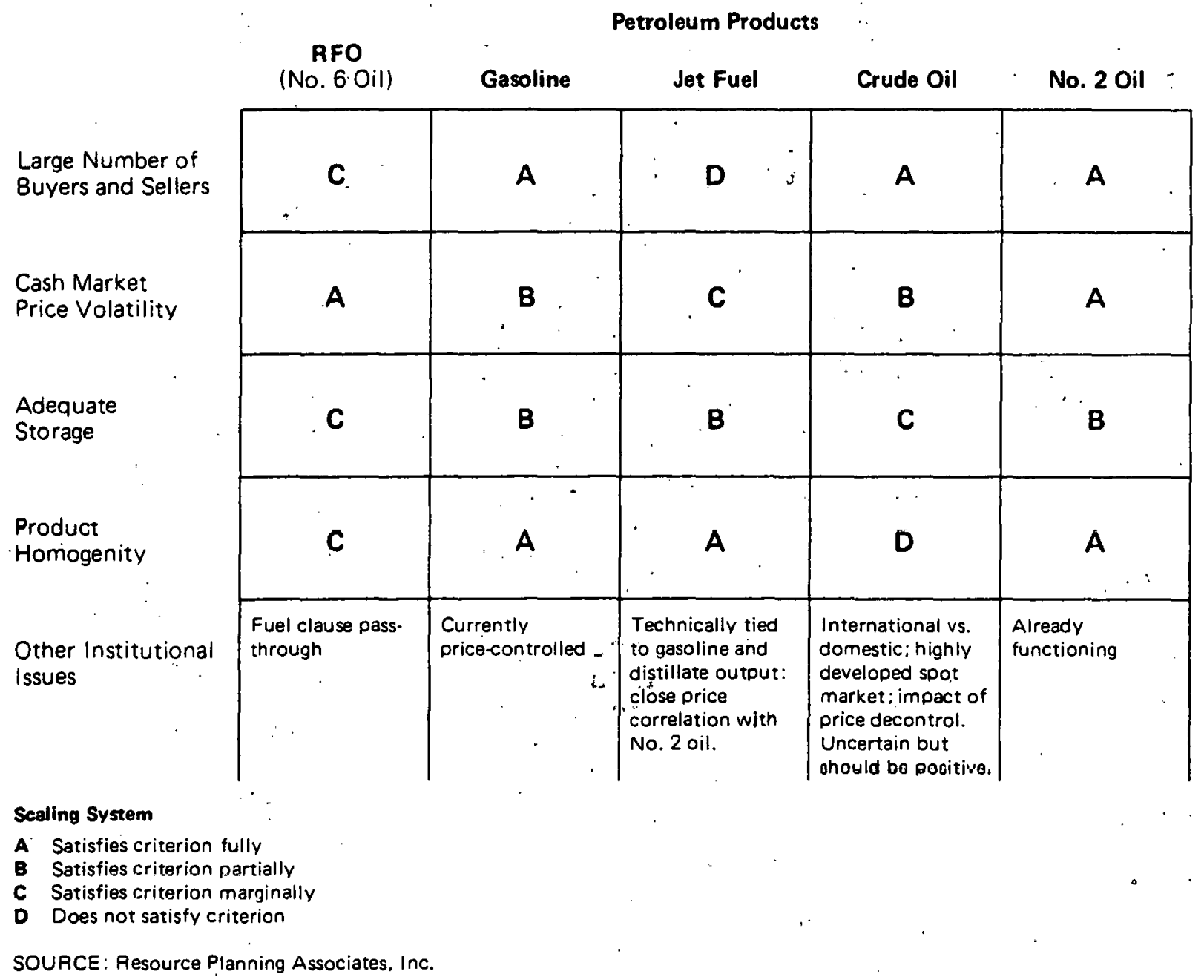


Another significant benefit that could accrue as a result of expanded futures trading is reducing the need for product price controls and allocations. Finally, increased futures market activity could spur the construction of storage in the New York Harbor area.

Among the potential costs of expanded petroleum futures market activity are the dangers of market manipulation and fraudulent trades. To prevent these from occurring, the NYME has established a number of regulations affecting price movements"and brokers. In addition, the NYME operates under the direction of the CFTC. As trades are cleared daily through the NYME's clearinghouse, detection of manipulation would be simple and rapid. To ensure that price manipulation does not occur, the NYME has improved ceilings and floors on daily price movements.

Another possible cost of expanded futures market development is the potential failure to deliver product. While the NYME has taken steps to ensure that product delivery occurs, some problems could arise if deliveries become larger than storage and transport facilities permitted. Given the history of declining proportion of deliveries relative to trading volume, that is unlikely to occur.

Delivery failures could also arise because of supply disruption (e.g.. Arab embargo). In that case, only contract markets would function; futures would have to declare

"force majeure." 
THIS PAGE

\section{WAS INTENTIONALLY}

LEFT BLANK 
Futures markets are affected not only by direct government regulation of market conduct and performance, but by indirect controls on prices and supplies. Trading in agricultural commodities, for example, is directly controlled by the commodities Futures Trading Commission (CFTC), which is empowered to maintain fair and orderly markets. In addition, the U.S. Department of Agriculture (USDA), through its agriculture commodity price support system and land "set-aside" programs, is able to influence the prices and supplies of many agricultural commodities. The CFTC, of course, is also responsible for ensuring that trading in No. 2 oil futures contracts, as well as trading in any other new futures contracts, is fair and orderly. Finally, DOE can wield significant influence over existing and prospective energy futures trading, owing to its broad power to regulate the prices and allocation of crude oil and petroleum products, its emergency standby regulations, and its strategic petroleum reserves program.

The objectives of the market regulator (the CFTC) and the interested federal departments, however, are not necessarily synonymous. The role of a futures market regulator is to ensure that the market is free from manipulation. On the other hand. federal agencies such as USDA and DOE have broad mandates to influence and maintain the prices of many commodities and products. Thus, there are different regulatory perspectives for the CETC -- the instrument of market regulation -- and the federal agencies empowered to control prices and supplies of commodities or products. In resolving this issue, the USDA's long experience as a regulator of commodities futures marketing as well as the commodities trades themselves is particularly relevant. 
Because DOE is currently formulating its position on existing and potential energy futures markets, it is important to understand the range of actions available to DOE policymakers and the consequences of each of these actions, both for the energy futures markets and industry competition. In this chapter, we describe the regulation of commodities futures markets by the CFTC and the USDA. Using this as a frame of reference, we then identify potential DOE policies regarding energy futures markẹs, and analyze theis probable consequences.

THE DIRECT REGULATION OF COMMODITY FUTURES MARKETS

Until 1974, when the CFTC was established, the USDA was responsible for regulating the nation's commodity exchanges as well as maintaining the price, supply, and quality of many of the commodities trades.

The present system of futures trading regulation, in which regulatory authority rests primarily with the CFTC, evolved as the result of increased trading volume and competitive pressures. Historically, the Grain Futures Act of 1922 enabled the USDA to regulate grain trading on the commodity exchanges. The exchanges were required to be federally licensed as "contract markets" and were responsible for the prevention of price manipulation and unfair market practices. However, the limited regulatory powers that were authorized to the exchanges were inadequate to deal with the many market abuses.

With the Commodity Exchange Act of 1936, the USDA's purview was extended to cotton and other commodities. At the same time, the USDA's authority to deal with market abuses by traders as well as by members was broadened and, for the first time, price manipulation was a criminal offense. The Act also set regulations to curb excessive speculation by large market operators and to suppress cheating, fraud, and fictitious transactions in futures by extending its authority to brokers. 
The Commodity Exchange Act of 1968 further expanded the regulation of the commodity futures market. Under the Act, commission merchants are required to meet specified minimum financial standards; the penalties for certain law violations such as manipulation and embezzlement are increased; the issuance of cease-anddesist orders is authorized; and contract markets are required to enforce their trading rules and contract terms. The Act also brought new commodities under regulation -- livestock, livestock products, and frozen concentratéd orange juice.

Until 1974, the Secretary of Agriculture regulated futures trading through the Commodity Exchange Authority (CEA) but his authority was limited to 1) approving trading on designated exchanges,

2) conducting disciplinary proceedings, and

3) promulgating regulations.* In addition to regulating the actual commodity exchanges, the USDA was, and. still is, rsponsible for setting commodity standards and grade specifications, and for enacting agricultural programs to support prices and income.

In the late 1960s and early 1970s, futures markets grew in several respects: record trading volumes were set, open interest increased substantially, the prices of many commodities rose, and the number of market participants increased. With the increased economic importance of commodities futures markets, the USDA's dual role as a market regulator and price maintainer became untenable. The movement to create a separate regulatory agency was spurred not only by the growing importance of futures trading, but by the fact that several very important futures markets had never been regulated: coffee, cocoa, lumber, various metals, and foreign currencies. As a result of these factors, the CFTC was created in 1974, replacing the CEA.

The CFTC regulates trading to prevent unreasonable or sudden fluctuations in the prices of commodity futures by establishing speculative limits, that is, by limiting the amount of trading and size of the position a speculator may hold. These limits are designed to lessen the impact that any one speculator can have on the market. Historically, as the sizes of an individual's trades or positions increase with 
respect to the total market and the activities of other traders, the impacts of those trades or positions on the market also increase. As a result, the competition in a given market decreases.

The CFTC was given substantially more authority than its predecessor agencies to enforce the mandate of the commodity Futures Trading Commission Act. It has the authority to obtain court injunctions and to litigate in court with its own attorneys; it ic also elupowered to deal with market emergencies and to conduct an education and research program. In addition, the CFTC is responsible for:

- Deslgnating as a contract market any exchange that demonstrates that the contract for which designation is sought will not be contrary to the public interest

- Reviewing and approving the bylaws, rules, regulations, and resolutions of designated contract markets that relate to trading requirements

- Processing, through administrative hearings, reparations claims by traders who allege monetary injury due to a violation of the act by anyone registered witri CFTC

- Regulating transactions in standardized margin or leverage account contracts in gold and silver bulk coin or bullion

Registering and examining the fitness of individuals who handle traders' accounts, of futures commission merchants, of commodity pool operators, and of commodity trading advisors

- Establishing additional delivery points for traded commodities

- Regularly inspecting designated contract markets

- Determining whether or not to allow certain trading practices (i.e., dual trading and commodity options trading)

- Considering the antitrust consequences of its acts. 
As the sole regulatory agency, the CFTC can conduct its own investigations of activities that might affect the market. Its enforcement staff of attorneys and investigators provides the legal expertise necessary for the successful prosecution of criminal charges. An example of such legal action occurred in 1977, when the CFTC and the U.S. District Court in Chicago ordered seven members of the Hunt family of Dallas to liquidate their existing positions in soybean futures trading on the Chicago Board of Trade because they had exceeded the speculative 1 imits.

USDA'S COMMODITY PRICE

AND SUPPLY CONTROLS

The USDA's role in regulating commodities markets is indirect but important. Price and income support programs are the principal means by which the USDA achieves such policy objectives as: maintaining the amount and stability of farm income, ensuring equitable treatment of producers in different regions, maintaining stable markets, expanding exports, and providing food aid.

\section{Commodity Price Supports}

Commodity price support legislation dates back to the passage of the Agricultural Adjustment Act in 1933.

The early programs under this Act were aimed at restoring farm purchasing power of agricultural commodities to the pre-world war I level. This goal became known as parity, or an equality of exchange between agriculture and industry. The parity price for an agricultural product is determined by formula. It is the dollars-and-cents price that will give a commodity the same buying power -in terms of goods and services bought by farmers and certain costs of their farming operations -- that it had in the 1910-1914 base period.

Current price support programs are carried out under the authority of the original Agricultural Adjustment Act of 1933, although it has been amended since that time. Today, support levels (e.g., the range within which loan, purchase, and payment rates are set) are established by Congress. 
The Commodity Credit Corporation (CCC), also created in 1933, is authorized to carry out a number of activities: the support of agricultural commodity prices through loans, purchases, payments, and other operations; and the procurement of agricultural commodities for sale to other government agencies, foreign governments; and domestic, foreign, or international relief or rehabilitation agencies.

In its work, the CCC seeks to ensure that cooperating farmers receive no less than the support price established for a particular commodity.* Commodities designated for price support are those that are critical to a stable agricultural economy, are subject to significant fluctuations in supply and demand, and for which such support will provide for a more orderly marketing by producers. Commodities that are candidates for price support. include wheat, corn, peanuts, rice, tobacco, wool, mohair, cotton, honey, barley, oats, rye, sorghums, milk, milk products, flax, soybeans, rosin, sugarbeets, and sugarcane.

To be eligible for these price support payments and loans, the farmer must participate in one of the ccc-run adjustment programs, which include set-aside and other cropland diversion provisions, acreage allotments, and marketing quotas for specified crops. The current set-aside plan replaces the crop acreage restriction of earlier programs. Under this plan, a participating farmer excludes from crop use an area of land equal to his share of the national 1 and diversion requirement. The land set aside is then used for approved conservation practices and not for other crops. The farmer may use the remaining cropland as he chooses, except for certain quota crops.

* The CCC also provides commodity loans. These loans are non-recourse, with the commodities serving as collateral. If market prices rise above the loan level, the producer can pay off the loan, with interest, and seli the crop on the market. If prices fall below the loan level, the producer can turn the commodity over to the CCC in full payment of the loan. 
The most important type of price support is deficiency payments, which guarantee the farmer a fair market price for the crop yield from the set-aside land. If the market price is low, he will be paid the difference between the market price and the target price set for that particular crop. The producer or farmer may also receive payments for diverting 1 and for crop production in order to maintain a reasonable balance between supply and demand.

\section{Effects of Price}

Support Programs

The USDA does not regard maintenance of the commodity futures markets as an important policy objective. Rather, the USDA's principal concern is stabilizing and protecting farm income and prices, and ensuring adequate supplies of agricultural commodities. In assessing the effects of USDA price supports on the commodities futures markets, it is important to understand that llost of USDA's price support programs were inaugurated long after commodities futures trading had become an established economic fact of life.

In general, a system of price supports will raise the overall level of prices, since the system provides a floor below which prices will not sink. During periods of rapid inflation like the present one, however, general agricultural price levels exceed the government-supported price. During an economic downturn, the price support programs, particularly government commodity purchases, will keep prices from falling.

DOE PETROLEUM LEGISLATION

AND REGULATIONS

In this section, we examine legislation and regulations that affect petroleum markets. Specifically, we discuss DOE petroleum price and supply controls, the Strategic Petroleum Reserve, and emergency standby regulations. 
DOE Energy Price

and Supply Controls

Unlike agricultural commodity price controls, price and supply controls on crude oil and certain petroleum products have significant influence on the growth and emergence of futures markets. This is because the purpose of federal energy price and supply regulations is different from that of agricultural support programs. Specifically, USDA price support programs are designed to protect producers (i.e., farmers) by ensuring a minimum price. DOE's complex array of price and supply regulations, on the other hand, is designed to protect consumers of petroleum products by means of price ceilings and rigid allocation rules.

The future development and growth of petroleum futures markets will depend largely on two factors. One is DOE's policy objectives. The other is the implementation of price and supply controls established in the Emergency Petroleum Allocation Act (EPAA), the emergency standby regulations mandated by the Emergency Energy Conservation Act (EECA), and the Strategic Petroleum Reserve established under the Energy Policy and Conservation Act.

In this section, we briefly describe the pertinent legislative and regulatory powers of DOE, the range of actions that DOE is empowered to take vis-a-vis the petroleum futures markets, and the ramifications of those actions.

The Emergency Petroleum Allocation Act of 1973

The EPAA gave the President temporary authority to "deal with shortages of crude oil, residual fuel oil, and refined petroleum products or dislocations in their national distribution system." Specifically, EPAA provided the authority for four basic programs.

(1) Continued crude oil price controls

(2) Crude oil cost equalization (entitlements)

(3) Petroleum product price controls 
(4) Mandatory petroleum product allocations.

The Energy Policy and Conservation Act of 1975 (EPCA) further expanded and altered petroleum price controls, extending EPAA's 1 ife until september 30,1981 . In July 1976, however, the Federal Energy Administration (FEA) exempted No. 2 heating oil, No. 2 diesel fuel, No. 1 heating oil, No. 1 diesel fuel, and kerosene from controls imposed under allocation and price regulations. A year later, No. 6 oil, or residual Euel oil, was exempted. Gasoline and crude oil are still affected by the EPAA price and allocation rules, while synthetic fuels processed from oil shale are not covered by the Act.

Under EPAA's legislative mandate, a number of important allocation regulations were issued.

The Supplier/Purchaser Freeze. Under the 1974 regulations, the relationships in the petroleum product distribution channels were frozen. As a result, suppliers are obligated to supply crude oil or petroleum products, but purchasers are not obligated to purchase. Shifts in the supplier-purchaser distribution chain are permissible if another purchaser can be found who will pay a higher lawful price than the current purchaser is willing to pay.

The single most important competitive impact of the supplier-purchaser freeze has been to erect barriers to new entry into refining and marketing. Because an entrant must come to the Economic Regulatory Administration (ERA) for a supplier assignment, the Act provides a clear competitive advantage to established firms.

A second effect of the regulations has been to "marry" suppliers and assigned purchasers. In theory, a purchaser can refuse his allocation, and a supplier can then dispose of the surplus on the spot market. In practice, however, customers with allocations of low-cost products are likely to accept the allocations and then resell the product. During periods of tight supply, the allocation rules discourage customers from shopping around for lowpriced products lest they permanently sever their supplier relationship. 
The Buy/sell program. The objective of the buy/sell program is to ensure availability of crude oil on an equal basis to all refiners. Specifically, the program was designed to guarantee allocations of crude oil to refiners in the interior of the United states during periods of excess demand. The program accomplishes this by allocating from large or integrated refiners, many of which are located on the eastern seaboard, to small or independent refiners, many of which are lucaled in the Interlor of the country.

The principal effects of the program are reduced competition as a result of limited market entry (and exit) and reduced incentives. Allocations to new refiners employ a weighting scheme that is based on such factors as alternative sources of supply and projected refinery capacity. Not only does the program make it difficult for new refiners to enter the market, but it serves as a barrier to market exit, because availability of crude oil is ensured.

By limiting input quantities, the buy-sell program has fixed the capacity utilization of refiners. Thus, refiner market shares are stabilized, and incentives for competition are reduced.

The Entitlements Program. As the price's of domesticcontrolled crude oil and foreign crude oil diverged in the early 1970s, cost differentials widened between refiners using controlled crude inputs and those using uncontrolled inputs. The entitlements program was established in 1974 in an attempt to equalize average crude oil costs to refiners. This was accomplished by allocating access to the relatively cheap price-controlled crude oil through a system of direct payments by entitlement "buyers" to entitlement "sellers." One "entitlement" gives the refiner the right to receive and refine one barrel of domestic price-controlled crude oil. 
The most significant effect of the entitlements program has been the equalization of output (product) prices, owing to the equalization of input (crude) prices. In effect, the entitlements system eliminated the ability of the refiners who had access to low-cost input to underprice competitors. This discourages market competition. Ultimately, the entitlements program serves to insulate refiners from market uncertainties.

\section{Strategic Petroleum Reserve}

As part of the nation's effort to reduce the impact of severe oil supply interruptions, the EPCA mandated the creation of a strategic Petroleum Reserve (SPR) for the storage of up to 1 billion barrels of petroleum products.

The SPR includes an Early Storage Reserve, for the storage of petroleum products in existing facilities; the stored products could be owned by private industry or by the U.S. government. The SPR also includes an Industrial Petroleum Reserve, in which importers of petroleum and refiners can be required to store a certain percentage of the product.

The SPR currently has a goal of 750 million barrels of storage by 1986 ; in June 1980, however, only 92 million barrels of crude oil were in storage. DOE's plans for purchasing oil to store in the SPR are unclear. The fiscal 1981 budget request calls for purchases to resume in June 1981, but there is considerable interest in Congress to fill the SPR more quickly.

\section{Emergency Standby Regulations}

Under the provisions of EPCA and the Emergency Energy Conservation Act (EECA), the President is authorized to develop and implement standby plans in the event of an energy shortage. These contingency plans include gasoline rationing, monthly conservation targets for petroleum products, and a standby federal conservation plan. 
This plan -- if implemented -- would pose particular problems for an existing futures market in a petroleum product. First, by restricting fuel use, a rationing or conservation plan would tend to curtail futures trading. Second, although futures markets are not specifically mentioned, a standby federal conservation plan would not be prohibited from specifically curtailing or limiting futures market trading as a means of obtaining supply. Under the regulations, the plan noed only bo consistent with F.PAA, but must not represent an undue burden on interstate commerce. The President is barred from imposing a tax, tariff, or user fee, or authorizing weekend closings of retail gasoline stations.

POSSIBLE DOE POLICY ACTIONS AFFECTING PETROLEUM FUTURES MARKET

While DOE is not directly responsible for the regulation of petroleum futures trading, it could take a number of actions that would influence the existing market in No. 2 oil and the development of markets in other petroleum products. Under EPPA and EPCA, DOE can control or decontrol crude oil and petroleum product prices, al though its authority to do so expires in 1981. The imposition of energy emergency standby rules could also affect the vitality of petroleum future markets. Finally, DOE could affect the volume of futures trading by building storage facilities and engaging in trading. In this section, we examine how DOE actions might affect the existing market in No. 2 oil.

In establishing a policy on the petroleum futures market, DOE must first decide whether the objective is to encourage or discourage the growth and development of such markets. While DOE could maintain an officially neutral posture regarding futures markets, in reality, many of its actions on behalf of other policy. goals will have important effects on futures markets. 
Policies Encouraging Futures Market Development

The principal barriers to further growth of futures trading are the lack of sufficient storage facilities in the northeast, the reluctance of major oil companies to participate in the market, and, to a lesser degree, apprehensions about future price and allocation controls. As mentioned previously, 35 percent of No. 2 oil contracts have so far culminated in delivery of product. To date, deliveries have not exceeded 500,000 barrels in a given month; if deliveries exceed 1-2 million barrels a month, however, storage facilities could become a problem. Thus, the availability of storage in New York Harbor may become critical to the continued growth of the futures market. In any case, the delivery mechanism of the No. 2 futures contracts reinforces the supply-demand relationship and the credibility of the market. Without the delivery mechanism, an equilibrium price could not be fully determined. With the mechanism, however, a seller trying to raise the price of the product by holding it in inventory and off the market would have to pay a premium for storage costs. Because he would not want to incur storage costs in excess of his anticipated future returns, the seller would tend to put his product on the market sooner to avoid high inventory costs.

To increase the amount of storage in New York Harbor, DOE could finance and construct storage facilities, which could be offered for lease to the private sector. Alternatively, DOE could enter into cost-sharing arrangements with the private sector. Given the relatively high cost of storage, such programs could provide necessary incentives to the construction of new storage facilities.

It is also worth considering the role such governmentsponsored storage construction programs might play in accomplishing another policy objective -- filling the SPR and the Industrial product Reserve. Under EPCA, for example, DOE can require importers and refiners to acquire and store petroleum products in existing facilities, as long as the amount stored is less than 3 percent 
of the total refined.or stored. * The government-owned storage facilities could be used as repositories for the product. Many obstacles, such as storage construction costs, stand in the way of such a program.

The hesitancy of some major oil companies and others to participate in petroleum futures markets can be attributed in part to the lack of a clear policy statement by DOE encouraqing their.participation. Their failure to participate also can be attributed to institutional inertia. Clearly, such participation in the futures market by major oil companies would increase activity in the existing No. 2 oil market. Moreover, the creation of new petroleum futures markets in crude oil and gasoline might be spurred by the support of the oil industry. .

All of the preceding DOE actions would tend to encourage futures market development. By encouraging the growth of petroleum futures markets, DOE would be able to achieve, at least in part, other policy objectives, such as an increase in industry competition, and an open and visible pricing merhanism.

Petroleum product prices can have an impact on crude oil prices, provided there is a mechanism for ensuring that buyers have as much leverage as sellers. A petroleum futures market would allow buyers that leverage. During periods of surplus markets, declines of product prices would influence crude oil markets more rapidly than now. As buyers of petroleum products bid down product prices, the refiner would either have to cut back his refinery

* Under EPCA, the Administrator of the SPR may:

(1) Acquire land for storage facilities by purchase or condemnation

(2) Construct, purchase, or lease storage facilities

(3) Acquire, purchase, or exchange petroleum products

(4) Store petroleum products in storage facilities owned by the U.S. government. 
runs until the product surplus disappears or seek lower crude oil prices from his suppliers. The refiner will take both of these actions to varying degrees today, but with the advent of futures trading, a declining product futures. price would give an important early warning signal to crude oil suppliers. As a result, crude oil producers, private oil companies, and OPEC-nation oil companies alike would react either by reducing crude oil production or by decreasing crude oil prices.

Each seller would have to react more quickly and to a greater degree than under the present system, thereby generating the potential for more competition among crude oil suppliers. Because the history of the petroleum industry has been one of surplus, the futures market could represent a limited but still important mechanism by which the surplus can be more visibly and rapidly translated into lower product price.

A futures market would reduce allegations by. oil industry critics that current product pricing policies are not competitive. In addition, the open market pricing concept would significantly reduce the regulatory burden on the federal government. The use of commodity exchange prices, which reflect true supply and demand conditions, is likely to be preferable to the regulatory burdens imposed on and by the government. The advent of successful futures markets in petroleum products could eliminate the need for product price controls, allocations, and entitlements.

Taken together, such DOE actions would encourage the future growth of the No. 2 oil futures market, and perhaps pave the way for the emergence of other energy futures markets. These actions are summarized in Exhibit 15.

Policies Discouraging

Futures Market Development

Principally, DOE could retard the development of petroleum futures markets by the imposition of price and allocation controls and straight standby conservation regulations. However, it must be noted that petroleum futures markets can adjust to moderate levels of price and supply regulations, as the commodities markets have done over time. Actions tending to retard the development of petroleum futures markets are summarized in Exhibit 16. 


\section{Exhiblt 15}

DOE Policies That :Vould Encourage

No. 2 Oil Futures Market

\begin{tabular}{|c|c|c|c|c|}
\hline Government Polloy & $\begin{array}{l}\text { Treding } \\
\text { Volume }\end{array}$ & $\begin{array}{l}\text { Number of } \\
\text { Pardedpents }\end{array}$ & Price & Supply \\
\hline $\begin{array}{l}\text { Building storage and } \\
\text { leasing it to private } \\
\text { firms }\end{array}$ & $\begin{array}{l}\text { Trading volume } \\
\text { would grow }\end{array}$ & $\begin{array}{c}\text { Number of } \\
\text { participants } \\
\text { would increase } \\
\qquad .\end{array}$ & Uncertain & $\begin{array}{l}\text { Supplies of } \\
\text { product in } \\
\text { futures market } \\
\text { would increase; } \\
\text { deliveries would } \\
\text { increase }\end{array}$ \\
\hline $\begin{array}{l}\text { Encouraging oil } \\
\text { companies to use } \\
\text { market }\end{array}$ & $\begin{array}{l}\text { Trading volume } \\
\text { would grow }\end{array}$ & $\begin{array}{l}\text { Number of } \\
\text { participants } \\
\text { would increase } \\
\text { dramatically }\end{array}$ & $\begin{array}{l}\text { Pricing mecti- } \\
\text { anism would be } \\
\text { more competi- } \\
\text { tive }\end{array}$ & $\begin{array}{l}\text { Supplies of } \\
\text { product in } \\
\text { futures markets } \\
\text { would increase }\end{array}$ \\
\hline
\end{tabular}

SOURCe: Resource Planning Associates, Inc. 
Exhibit 16

DOE Policies That Would Discourage

No. 2 Oil Futures Market

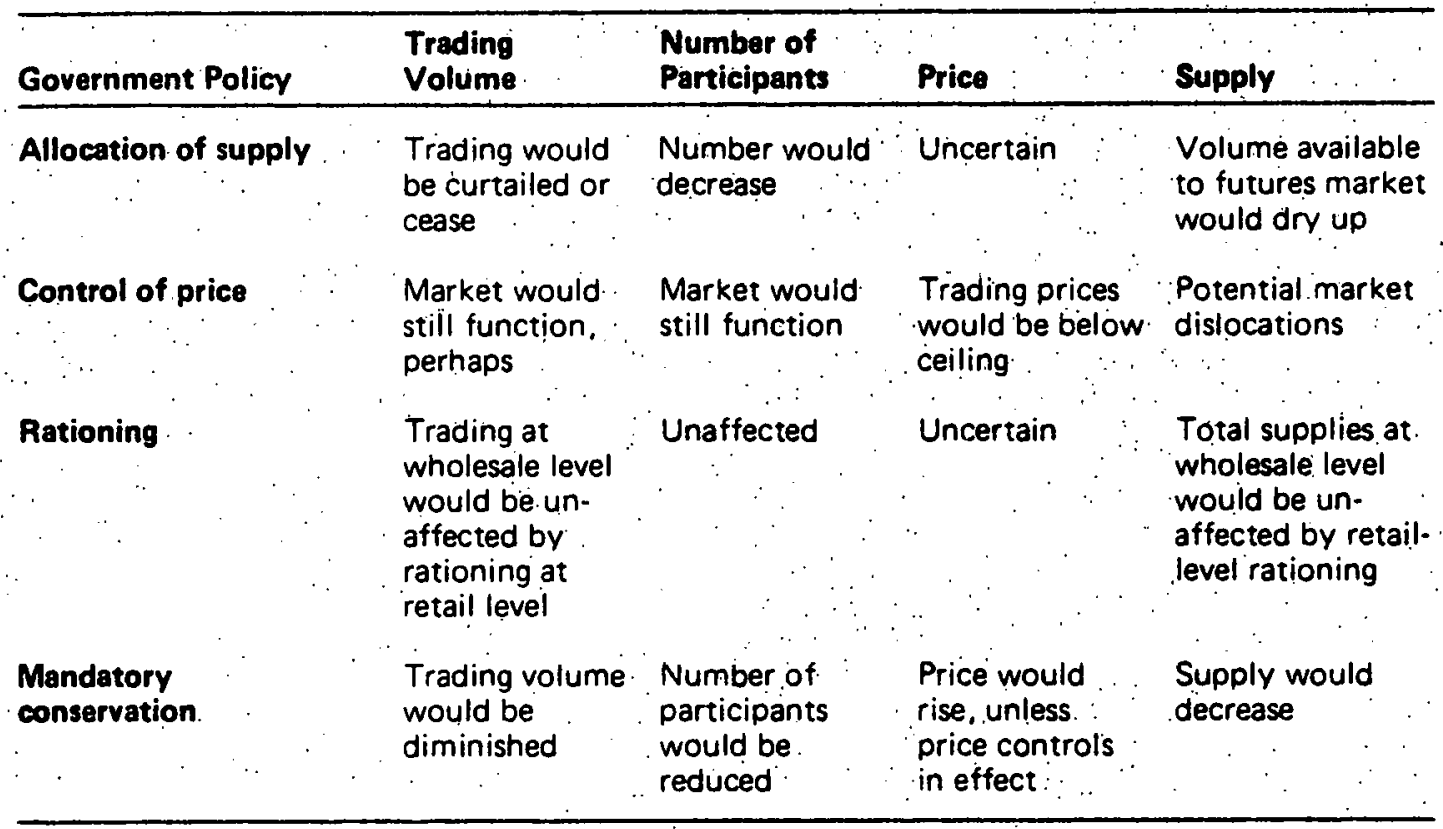

SOURCE: Resource Planning Associates, inc. 
Allocation controls. Under EPAA, allocation controls can be imposed on No. 2 oil. Such reimposition would tend to reduce or curtail completely futures.trading in No. 2 oil, because the allocation rules tie together supplies and purchases. Allocation regulations are likely to be reimposed, however, only in the event of a severe shortage, in. which case there would be little supply to divert to the futures market. In this event, a "force majeure". is likely to be invoked in the futures and spot markets.

Experience with allocation regulations of gasoline, in particular, has demonstrated that a principal result is dislocation of product. Thus, one region may have a surplus of product while other areas may have shortages. Where these dislocations exist, middlemen (e.g., resellers) step in, which constitutes the spot market. Thus, if allocation controls were reimposed, the futures market would operate -- if at all -- in a limited way; it would be, in effect, a spot market, serving to reequalize supplies. With allocation controls, futures pricing would become highly risky and trading would take place over very short periods of time.

Imposition of price controls. If price controls were reimposed on No. 2 oil, the futures market, in theory, would not be able to operate. But in practice, the reimposition of margin regulations, like allocation controls, would cause the futures market in No. 2 oil to function as a spot market.

In futures trading, market participants maintain arm'slength relationships, facilitated by the clearinghouse through which buys and selis are impersonally matched. Price control rules, if imposed on No. 2 oil, would violate the concept of arm's-length transactions. Under present margin rules, the maximum permissible selling price for a petroleum product is the sum of product costs (i.e., acquisition costs) and non-product costs (i.e., the margin). Thus, to determine the maximum allowable selling price of a product, the source and, cost of the product must be known and identified. In the spot market, traders of petroleum products generally compute a monthly average of selling and acquisition costs to determine whether they are within the permissible margin 1 imits. 
As stated above, if price regulations were imposed on No. 2 oil, the existing futures market would begin functioning as a spot market, as a result of the need to abide by government price.regulations. of course, in the event that price and allocation regulations were imposed, the futures market would cease to exist.

Rationing or imposed conservation. In the event that supplies of No. 2 oil were so scarce that rationing or some form of stringent conservation were imposed, there would be little product for either the spot or futures market. Because of thin supplies, the board of the New York Mercantile Exchange would have to declare force majeure and cease trading for the duration. As in any market, futures, spot, or contract, outstanding legal obligations would have to be settled, and could at times lead to litigation. In periods of excess demand, the maintenance of the contract market would grow, as users attempted to ensure sources of supply. A system of rationing, by itself, would have little effect on futures trading. The rationing of No. 2 oil by means of coupons, as is contemplated for gasoline, simply transfers demand at the retail level. Futures markets, however, function at the wholesale level.

\section{SUMMARY}

As indicated by the performance of the futures market in No. 2. oil, petroleum futures markets can have a number of beneficial effects on petroleum pricing and distribution. First, the futures :market represents a limited but still important mechanism that allows the existence of surplus product to be quickly made known and rapidly translated into lower product prices. Second, an open and visible pricing mechanism makes the petroleum industry more competitive, thereby helping to allay criticism that current product pricing practices do not reflect supply and demand. Finally; the advent of a large and viable futures market could eventually eliminate the need for product price controls, product allocations, and even entitlements. 
If the government wishes to pursue a course that encourages the growth of the futures market in No. 2 oil as well as the development of futures markets in gasoline, jet fuel, and crude oil, a range of policy initiatives is open to it. The principal actions that would tend to encourage petroleum futures markets are the elimination (or lessen-. ing) of price and supply controls, the building of storage facilities in the northeast and the Gulf Coast, and the urging of oil companies to participate in futures trading.

Conversely, the reimposition of price and supply controls, the failure to encourage participation by oil companies, and the stringent conservation of fuels in the event of a severe supply interruption would tend to dampen or stifle development of petroleum futures markets. 


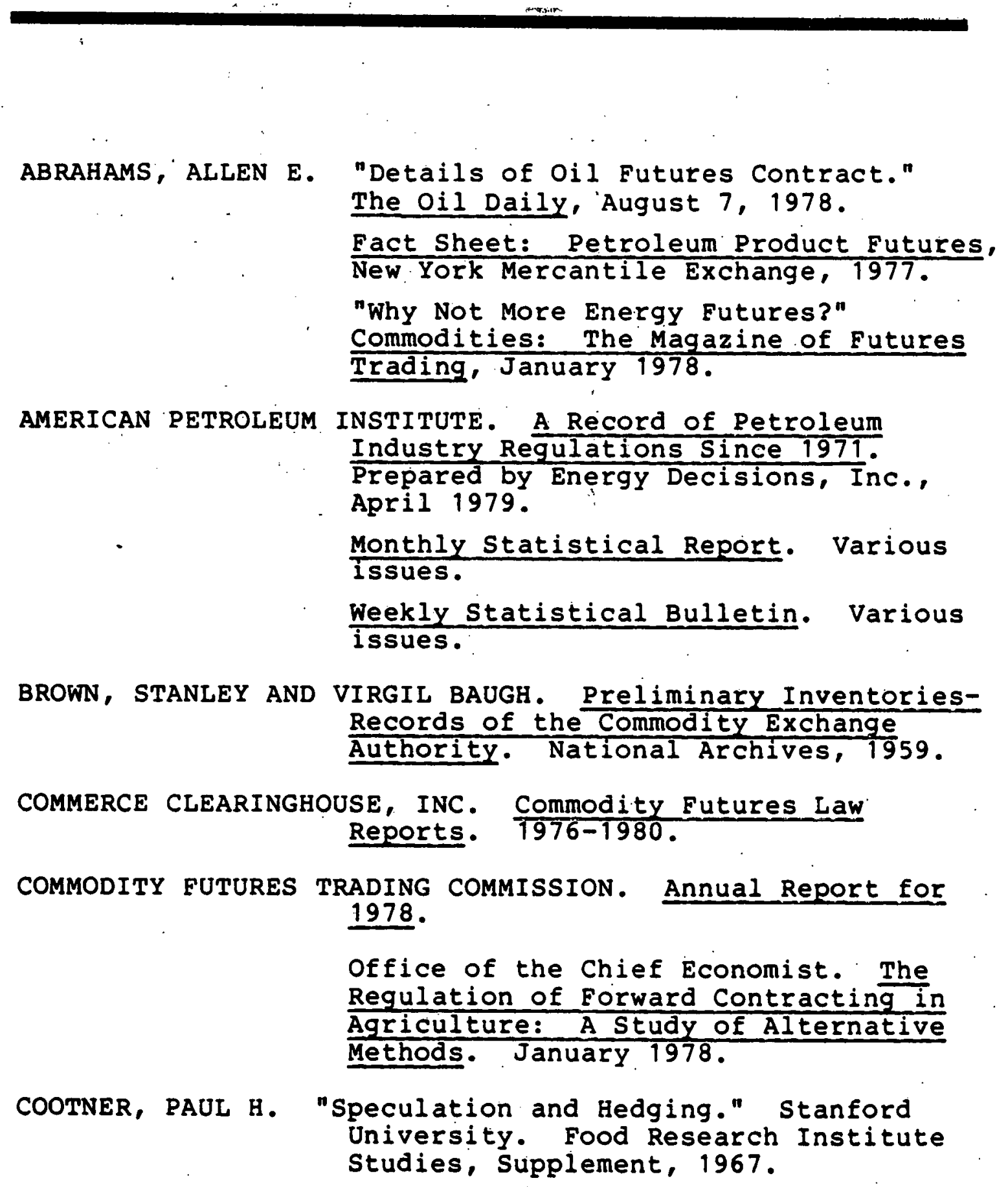


CROLY, WILLIAM G. The Role of Futures for Buyer and

Seller. The Energy Bureau.

DUSAK, KATHERINE: "Futures Trading and Investor Returns: An Investigation of Commodity Market Risk Premiums." Journal of Political Economy; December 1973.

EMERGENCY ENERGY CONSERVATION ACT. OF 1979.

EMERGENCY PETROLEUM ALLOCATION ACT OF 1973.

ENERGY POLICY AND CONSERVATION ACT OF 1975.

ERRERA, STEVEN. Section 15, Petroleum Product Futures

Contracts, U.S. Delivery. The Energy Bureau, 1978.

The Futures Delivery Process. The Energy Bureau, 1979 .

FURLONG, TOM. "Can Petroleum Futures Soothe wild

Oil Market?" Chicago Sun Times,

March 24, 1980 .

JACOBS, ALLEN. The New Futures Market in Petroleum

Products. U.S. Department of Energy,

Office of International Market

Analysis. April 1979.

JOURNAL OF COMMERCE. "Heating Oil Futures seen as Visible Mart." January 25, 1979.

GRAY, ROGER W. "Price Effects of a Lack of Speculators." Stanford University Food Institute

studies. Vol. VIII, 1967.

HOUTHAKKER, H.S. "Can Speculators Forecast Prices?"

Review of Economics and Statistics.

Vol. XXXIX, No. 2, 1957 (pp. 143151).

"Normal Backwardation," in J.N. Wolfe, ed.. Value, Capital and Growth:

Papers in Honour of Sir John R. Hicks. Edinburgh University Press, 1968. 
LARSON, ARNOLD B.

"Measurement of a Random Process in. Futures Prices." Stanford University Food Research Institute studies. Vol. 1, No. 3. November 1960.

MAIDENBERG, H.J. "How to Hedge in Heating Oil." New . York Times, December 2, 1979.

MERRILL LYNCH. Guide to Technical Analysis: Introduction to Chart Analysis of Commodity Futures Trends. 1978.

MUIR, FRED. "Brokers See Futures Market Taking Over Oil Pricing." Energy Users News, May 5, 1980.

NEW YORK MERCANTILE EXCHANGE. Faber's Petroleum Futures Report. Published by Joel Faber. Various issues.

Hedging Energy Futures, Risk Management Through Commodity Futures. 1978.

Monthly Report. Various issues.

Petroleum Futures Information Kit.

PETROLEUM INTELLIGENCE WEEKLY. "Oil' Firms Begin to Test the Workings of Futures Trading." March 12, 1979.

PRICE, ROBERT SS. JR. "A Petroleum Futures Market." U.S. Department of Energy, office of Policy, and Evaluation, January 16 , 1980.

RASMUSSEN, WAYNE D. AND GLADYS L. BAKER. Price Support and Adjustment Programs From 1933 Through 1978: A Short History (Agriculture Information Bullet in No. 424). U.S. Department of Agriculture, February 1979.

RESOURCE PLANNING ASSOCIATES, INC. Petroleum Futures Advisory Service. 1979 . 
ROSEnBlaUm, CLARENCE. "New Oil Futures Contracts to Begin." Journal of Commerce, August 24, 1978 .

RUSTIN, RICHARD E: "SEC Weighs Rule That Securities Houses set Up Separate Firms for Commodities." Wall street Journal, May 2, 1980.

SAFER, ARNOLD. International oil Policy. Lexington Books, 1979.

SPURGA, RONALD. Hedging Petroleum Futures: The Banker's Viewpoint. The Energy Bureau.

TELSER, LESTER G. "Wheat Studies." 1934.

TOMEK, WM. AND ROGER GRAY. "Temporal Relationships Among Prices on Commodity Futures Markets: Their, Aflocative and Stabilizing Roles . Selected writings on Futures Markets, A.E. Peck, ed., Chicago Board of Trade, 1977.

U.S. DEPARTMENT OF AGRICULTURE. Annual Reports of the Commodity Exchange Authority.

Structure Issues of American Agriculture (Agricultural Economic Report No. 438). November 1979.

Agricultural stabilization and Conservation Service. The Commodity Credit Corporation and its Activities (ASCS Background Information Bulletin No. 4). April 1980.

Loan, Purchase and Payment Programs (ASCS Background Information Bulletin No. 5). November 1979. Production Adjustment Programs (ASCS Background Information Bulletin No. 6). September 1978 . 
U.S. DEPARTMENT OF ENERGY. Weekly Petroleum Status

Report. Various issues.

Middle Distillate Market Profile Report. Prepared by R. Shriver Assocíates, July 1979.

Energy Information Administration. The Effect of Legislative and Regulatory Actions on Competition in Petroleum Markets. Aprif 1979.

Economic Regulatory Administration, Office of Petroleum Operations. Middle Distillate Market Profile. July 1979.

U.S. GENERAL ACCOUNTING OFFICE. Regulation of the Commodity Futures Markets - - What Needs to be Done (Comptroller General's Report to the Congress). May $17,1978$.

U.S. SENATE, Committee on Agriculture and Forestry. The Commodity Futures Trading Commission Act of 1974. November 15, 1974.

VAN VACTOR, SAMUEL A. Reducing Risk with a Futures Market. Portland State University, Northwest Energy Policy Workshop.

WALL STREET JOURNAL. "Exchange Aides Oppose More Regulation to Prevent Speculation. Like the Hunts'." May 2, 1980.

"Peru Sustained: Loss of About $\$ 80$ Million Because of Speculation in Silver Futures." February 15, 1980.

"Silver's Slide Bloodies Only Hunt Brothers, and They're Unbowed." March 31, 1980 . 
BOARD OF TRADE OF THE CITY OF CHICAGO. Introduction to Hedging. 1978.

GOLD, GERALD. Modern Commodity Futures Trading. Commodity Research Bureau, Inc., 1975.

HIERONYMUS, THOMAS A. Economics of Futures Trading for Commercial and personal profit. Commodity Recearch Bureau, Inc., 1971.

MERRILL LYNCH. The Hedgers Handbook. 1971. SHARPE, WILLIAM F. Investments. Prentice-Hal1, Inc., 1978. 
UNITED STATES

DEPARTMENT OF ENERGY

WASHINGTON, D.C. 20585

OFFICIAL BUSINESS

PENALTY FOR PRIVATE USE, $\$ 300$
POSTAGE AND FEES PAID

U.S. DEPARTMENT OF ENERGY DOE 350

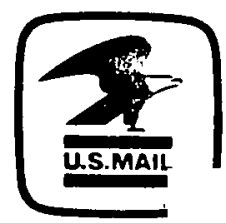

